\title{
Improving antibody-based cancer therapeutics through glycan engineering
}

Xiaojie Yu ${ }^{1, *}$, Michael J.E. Marshall ${ }^{1}$, Mark S. Cragg ${ }^{1}$, and Max Crispin ${ }^{2,3 *}$

${ }^{1}$ The Antibody and Vaccine Group, Cancer Sciences Unit, University of Southampton, Faculty of Medicine, General Hospital, Southampton, SO16 6YD, UK.

${ }^{2}$ Oxford Glycobiology Institute, Department of Biochemistry, University of Oxford, South Parks Road, Oxford OX1 3QU, United Kingdom

${ }^{3}$ Department of Immunology and Microbial Science, The Scripps Research Institute, La Jolla, California 92037, United States

*Correspondence: max.crispin@bioch.ox.ac.uk, x.yu@soton.ac.uk 


\begin{abstract}
Antibody-based therapeutics have emerged as a major tool in cancer treatment. Guided by the superb specificity of the antibody variable domain, they allow the precise targeting of tumour markers. Recently, eliciting cellular effector functions, mediated by the Fc domain, have gained traction as means by which to generate more potent antibody therapeutics. Extensive mutagenesis studies of the Fc protein backbone has enabled the generation of $\mathrm{Fc}$ variants that more optimally engage the $\mathrm{Fc} \gamma$-receptors $(\mathrm{Fc} \gamma \mathrm{R})$ known to mediate cellular effector functions such as antibody-dependent cellular cytotoxicity (ADCC) and cellular phagocytosis (ADCP). In addition to the protein backbone, the homodimeric Fc domain contains two opposing N-linked glycans, which represent a further point of potential immunomodulation, independent of the Fc protein backbone. For example, a lack of core fucose usually attached to the IgG Fc glycan leads to enhanced ADCC activity, whereas a high level of terminal sialylation is associated with reduced inflammation. Significant growth in knowledge of Fc glycosylation over the last decade, combined with advancement in genetic engineering, has empowered glyco-engineering to fine-tune antibody therapeutics. This has culminated in the approval of two glyco-engineered antibodies for cancer therapy: the anti-CCR4 Mogamulizumab approved in 2012 and the anti-CD20 obinutuzumab in 2013. We discuss here the technological platforms for antibody glyco-engineering, and review the current clinical landscape of glycoengineered antibodies.
\end{abstract}

\title{
Key Points
}

Antibody glycosylation can significantly influence clinical efficacy.

Design and selection of antibody glycoforms offers a route to enhanced therapies. 


\section{Introduction}

Since the approval of rituximab in 1997, the first monoclonal antibody (mAb) approved for the treatment of cancer antibody-based therapies have revolutionized the field of clinical oncology ${ }^{1-2}$. The success of rituximab has driven an explosion of interest in antibody therapeutics and fostered the desire to identify other therapeutic targets and to augment antibody efficacy through protein engineering ${ }^{3}$. As of June 2016, 24 mAbs, mostly human IgG-based, had been approved by the Food and Drug Administration (FDA) for the treatment of solid or haematological tumours $^{4-6}$.

Antibodies used in cancer treatment can be broadly classified into two categories based on their target type. The conventional 'direct targeting' class of cancer antibodies, comprising the majority of approved antibodies such as the anti-CD20 rituximab and anti-Her2 trastuzumab, target tumour cells by direct engagement of either lineage specific antigens (e.g. CD20), tumour neoantigens (e.g. glycans) or overexpressed oncogenic antigens (e.g. EGFR) After antibody engagement, the tumour cells are selectively depleted via various routes such as signalling-induced apoptosis or Fc-mediated complement-dependent cytotoxicity (CDC), antibody-dependent cell-mediated cytotoxicity (ADCC) and/or antibody-dependent cell-mediated phagocytosis (ADCP), depending on the nature of the antibody, target antigen and epitope ${ }^{7}$. The second class of anti-cancer antibodies, so-called immunomodulatory mAbs do not directly engage the tumour cells but rather target receptors on cells of the host immune system in an attempt to stimulate increased activity, principally through cytotoxic CD8+ T cells ${ }^{8-10}$. Antibody immunotherapy of this type came to the spotlight when the first immune "checkpoint blocker" antiCTLA4 mAb ipilimumab received approval to treat advanced melanoma, following the demonstration that it could significantly improve the prognosis for a proportion of patients with this aggressive malignancy ${ }^{11}$.

Despite the evident clinical efficacy of anti-cancer antibodies, their modes of action are often incompletely understood. It is generally accepted that for the conventional direct-targeting antibodies, the variable domain targets the tumour-selective antigen, conferring specificity, while the Fc domain mediates the elimination of tumour cells via the host immune system ${ }^{12-13}$. However, antibodies designed to effectuate through the blockade of signal transduction, such as the anti-her2 trastuzumab, may also work in part through the same mechanisms and moreover could attain additional functionality through Fc engineering. The relative contribution of the variable and Fc domains to the immunomodulatory mAbs is currently unclear. For example, agonistic anti-CD40 mAbs, which stimulate host antigen-presenting cells to potentiate an immune response against the tumour by activating CD40, a tumor necrosis factor receptor (TNFR), were also found to require the Fc domain for therapeutic efficacy ${ }^{14}$. However, the specific Fc $\gamma R$ required was shown to be entirely different to that engaged by direct targeting $\mathrm{mAb}$ in several pre-clinical models ${ }^{14-18}$. Moreover, isotype-switching to the less common IgG2 obviated the need for the Fc domain, resulting in Fc-independent agonistic activity ${ }^{15}{ }^{19}$. Similar paradigms have been seen with other TNFR targets, demonstrating that the $\mathrm{Fc}$ and its interaction with $\mathrm{Fc} \gamma \mathrm{R}$ are critical in delivering therapeutic responses for many antibody classes ${ }^{15,20}$.

\section{Rationale for antibody glyco-engineering}

\subsection{The Fc-FcyR engagement}


The general requirement of the IgG Fc domain for a fully functional cancer antibody has prompted the use of Fc engineering to improve the efficacy of $\mathrm{mAb}$ effector functions. The IgG Fc engages a set of Fc $\gamma \mathrm{Rs}$ that are expressed predominantly on immune effector cells to mediate effector functions ${ }^{21-22}$. These Fc $\gamma$ Rs are categorized into either activatory or inhibitory based on their intracellular signalling motif. The human activatory Fc $\gamma \mathrm{Rs}$, Fc $\gamma$ RI, Fc $\gamma$ RIIa, Fc $\gamma$ RIIc, and Fc $\gamma$ RIIIa, contain an intracellular activatory immunoreceptor tyrosine-based activation motif (ITAM) signalling motif within the cytoplasmic domain of the receptor (Fc $\gamma$ RIIa and IIc) or on the associated FcR $\gamma$ chain; while the sole inhibitory Fc $\gamma$ RIIb contains an inhibitory immunoreceptor tyrosinebased inhibitory motif (ITIM) within its cytoplasmic domain ${ }^{22-23}$. Humans additionally express another Fc $\gamma$ R, $\mathrm{Fc} \gamma \mathrm{RIII}$, which is highly homologous to Fc $\gamma \mathrm{RIII}$ in its extracellular domain but contains no transmembrane or intracellular regions, instead being anchored to the membrane through a glycophosphoinositol anchor and expressed solely on neutrophils ${ }^{24}$. Mice express 4 homologs: 3 of which (Fc $\gamma$ RI, Fc $\gamma$ RIII and Fc $\gamma$ RIV) are activatory while Fc $\gamma$ RIIb is inhibitory, as in humans ${ }^{25}$.

In humans, the activatory Fc $\gamma$ RIIIa is widely regarded to be the most important for delivering Natural Killer (NK) cell-mediated ADCC as Fc $\gamma$ RI and IIa are not expressed on these cells and Fc $\gamma$ RIIc is only expressed in a relatively small proportion of people due to the presence of a stop codon ${ }^{26}$. Furthermore, a functional polymorphism present within Fc $\gamma$ RIIIa at position 158, which alters the receptor's affinity for IgG1 and 3, has been reported to significantly affect the clinical response to rituximab therapy ${ }^{27-28}$. The importance of effective Fc-Fc $\gamma \mathrm{R}$ engagement for anti-tumour antibody efficacy has led to exhaustive Fc mutagenesis studies, which have identified residues critical for $F c \gamma R$ engagement and also enabled the generation of $F c$ variants that selectively engage specific Fc $\gamma R$ s $^{29}$. Many of these characterisations were carried out in vitro in systems where the mAb of interest represents the dominant antibody, which fails to recapitulate the in vivo environment where a high concentration of endogenous serum IgG (approximately $10 \mathrm{mg} / \mathrm{ml}$ ) will compete with exogenously administered therapeutic antibodies for Fc $\gamma \mathrm{R}$ engagement ${ }^{30}$. Weakening such intrinsic endogenous $\mathrm{IgG}-\mathrm{Fc} \gamma \mathrm{R}$ interaction, through the inactivation of serum IgG Fc, a strategy termed "receptor refocusing", could effectively improve the activity of therapeutic $\mathrm{mAbs}^{31}$.

\subsection{Antibody glycosylation and FcyR engagement}

Besides protein mutagenesis, antibody Fc glycosylation could also significantly modulate the Fc-Fc $\gamma \mathrm{R}$ interaction, through its conserved N-linked oligosaccharide attached to the Asparagine $297^{32}$. Antibody N-glycosylation occurs co-translationally in the lumen of the ER and initially follows a highly conserved and well-delineated pathway involving the transfer of a large pre-assembled glucosylated oligomannose-type oligosaccharide. As the protein transits from the ER and through the Golgi apparatus, different glycan transferases and glycosidases, add or remove different monosaccharides to create a diverse range of oligosaccharides differing in size and complexity. The diversity of IgG Fc glycoforms, like the myriads of other glycoproteins, arises from both the cellular environment and the intrinsic three-dimensional structure of the protein. However, despite the potential for considerable chemical heterogeneity IgG Fc glycosylation is characterized by a predominant population of glycans displaying limited processing of terminal residues giving rise to a characteristic fingerprint of glycoforms with partial galactosylation. 
Our current understanding of how the Fc glycan regulates antibody function has undergone a recent transition from being a simple structural support to a major immunomodulating agent. Early evidence supporting the importance of Fc glycan came from in vitro studies where IgG deglycosylation abrogated its effector functions ${ }^{33-}$ ${ }^{35}$. Since then, divergent activities of various IgG glycoforms, whether naturally occurring or engineered, have firmly established its immune-modulatory potential. The first clinical association was noted in rheumatoid arthritis patients, where a lack of terminal galactose in the IgG Fc glycoforms was correlated with disease induction, suggesting a pro-inflammatory role of agalactosylated glycoforms ${ }^{36}$. This was further supported by reports that the typical period of symptom remission noted during pregnancy was associated with a decrease in the level of agalactosylated IgG glycans ${ }^{37-39}$. Furthermore, HIV controllers who demonstrate better viral containment exhibit globally more agalactosylated $\mathrm{IgG}$ glycoforms ${ }^{40}$. In contrast to agalactosylation, more recently, it was described that $\mathrm{Fc}$ bearing terminal $\alpha 2,6$-linked sialic acids possess general anti-inflammatory effects in vivo ${ }^{41-42}$ and this effect may be influenced by the fucosylation status ${ }^{43}$

Besides galactose and sialic acid, the monosaccharide that has the most explicit influence on antibody therapeutics is the core fucose; fucose $\alpha 1$,6-linked to the protein-proximal GlcNAc residue. Engineered IgG Fc that lacks the core fucose was initially found to display significantly enhanced ADCC through improved engagement with Fc $\gamma$ RIIIa, an observation reproduced by many independent laboratories since ${ }^{44-48}$. The crystal structures of fucosylated Fc in complex with the human Fc $\gamma$ RIIIa elegantly illustrate how the receptor glycan clashes with the antibody fucose; a conflict which is resolved with afucosylated Fc, explaining its enhanced affinity ${ }^{48-49}$ (Figure $1)$.

\subsection{Fc engineering and immunogenicity}

The human immune system is well known for its ability to recognise and reject foreign entities, through both humoral and cell-mediated response. Therefore, it is not surprising that, for example, patients receiving the chimeric mouse/human anti-CD20 rituximab can elicit a human anti-mouse antibody immune response directed against the remaining mouse framework regions upon first exposure, which then complicates repeated use due to hypersensitivity reactions and reduced $\mathrm{mAb}$ half-life ${ }^{50-51}$. Site-directed mutagenesis of native antibody $\mathrm{Fc}$ domains, which dominates the current landscape of Fc engineering, could therefore potentially spawn Fc neoimmunogens, even though there is a lack of such reports in the current literature. On the contrary, Fc glycoengineering, predicated on the appendage of defined endogenous glycoforms, may in fact circumvent immunogenicity.

Nevertheless, for mAbs produced in non-human cell-lines, the impact of glycosylation on antibody immunogenicity has been recognised as a potential issue. For example, the anti-epidermal growth factor receptor (EGFR) cetuximab, which contains both Fab and Fc N-linked glycans, was found to contain the non-human glycan structure galactose- $\alpha 1,3$-galactose in its Fab glycans when produced in mouse Sp2/0 cells ${ }^{52-53}$. Humans express natural IgG reactive towards galactose- $\alpha 1,3$-galactose, and it was discovered that patients with high levels of preexisting anti-galactose- $\alpha 1,3$-galactose IgE, a class typically associated with allergy, displayed a hyper-sensitivity reaction to cetuximab ${ }^{54-55}$. Interestingly, the same cetuximab-specific IgE antibodies isolated from patients that had demonstrated hypersensitivity did not react with cetuximab produced in CHO cells which naturally lack $\alpha 1,3$ - 
galactosyltransferase activity. This further highlights the importance of antibody glycosylation and the choice of appropriate host cell line for therapeutic antibody production.

Given the immunomodulatory capacity of Fc glycan, glyco-engineering presents a viable path besides protein engineering to optimize the therapeutic activity of anti-tumour antibodies. As fucose engineering dominates the current portfolio of tumour-targeting antibodies, we focus this review on platforms for fucose engineering, and discuss fucose-engineered antibodies. It is however important to note that other means of glyco-engineering could prove equally useful in the future, especially for the immunomodulatory antibodies whose glycoforms remain largely unexplored.

\section{Platforms for fucose engineering}

IgG Fc with a low level of core fucose engages Fc $\gamma$ RIIIa and $\mathrm{Fc} \gamma \mathrm{RIIIb}$ with higher affinity and therefore leads to enhanced ADCC and ADCP ${ }^{56-58}$. This finding had triggered extensive research into methods for generating low fucose or fully afucosylated IgG. Several major methodologies have emerged to be applicable in making therapeutic antibodies.

\subsection{Genetic modification of the host biosynthesis pathway}

Altering the endogenous host $\mathrm{N}$-glycosylation pathway could either reduce or completely remove fucose from antibody Fc. In a landmark study by Umana and colleagues, it was discovered that overexpressing the GnTIII enzyme, which catalyses the addition of bisecting GlcNAc, in $\mathrm{CHO}$ cells led to the production of recombinant IgG1 mAb with significantly reduced core fucosylation, associated with higher ADCC in vitro ${ }^{58}$. The technology based on this GnTIII overexpression for generating low fucose therapeutics is referred to as GlycoMab, which was acquired by Roche ${ }^{59}$. The addition of bisecting GlcNAc to Fc glycan by GnTIII pre-empts the downstream action of the $\alpha 1,6$-fucosyltransferase; thus, bisecting GlcNAc acts as a competitive inhibitor of core fucosylation and overexpression of GnTIII in mammalian cells provides a means of producing IgG with low fucose ${ }^{60}$. To further diminish the fucose level, the same group engineered a recombinant form of GnTIII, which possesses the localization motif of the Golgi $\alpha$-mannosidase II, whose overexpression gave rise to approximately $60-70 \%$ afucosylated complex and hybrid type glycans ${ }^{61}$. As we will discuss later, this GnTIII-engineered platform forms the basis of producing obinutuzumab, the recently approved anti-CD20 mAb used for the treatment of nonHodgkin's lymphoma (NHL) and chronic lymphocytic leukemia (CLL). While the impact of bisecting GlcNAc predominantly impacts ADCC through its inhibitory effect on core fucosylation, there are some indications that GlcNAc might modulate receptor affinity independent of this effect ${ }^{62}$.

Although the overexpression of GnTIII in a cell line leads to reduced levels of fucose, this is not complete and there remains significant room for improvement, i.e. complete defucosylation. One means of achieving this involves genetically disabling the $\alpha 1,6$-fucosyltransferase encoded by the FUT8 gene. Just such a FUT8 knockout (KO) cell line was generated in $\mathrm{CHO}$ cells via homologous recombination, and lead to the production of $100 \%$ afucosylated antibodies ${ }^{63}$. This FUT8 KO antibody production platform was coined Potelligent technology, and was the system used to develop the anti-Cysteine-Cysteine chemokine receptor 4 (CCR4) mAb, mogamulizumab, the first approved glyco-engineered antibody ${ }^{64}$ (see Section 4.1). Another means of dampening $\alpha 1$,6- 
fucosyltransferase activity involves siRNA targeting of FUT8. Unfortunately, these reagents are not highly efficient, reducing FUT8 transcription by only $20 \%$ resulting in approximately $60 \%$ afucosylated $\operatorname{IgG}^{65}$.

Apart from a direct FUT8 gene KO, a second approach involves interfering with the GDP-fucose de novo biosynthesis pathway, whose resulting substrate GDP-fucose is essential for routinely cultured cells to produce fucosylated glycoproteins. One target enzyme in the pathway, the GDP-mannose 4,6-dehydratase (GMD), is involved in the catalytic process of converting D-glucose to GDP-fucose, the substrate of $\alpha 1,6$-fucosyltransferase that is indispensable for IgG core fucosylation ${ }^{66}$. $\mathrm{CHO}$ cells deficient in the GMD gene showed a complete lack of GDP-fucose, and in the absence of exogenous L-fucose produced $100 \%$ afucosylated IgG ${ }^{67}$. Yet another means of interfering with GMD activity involves the heterologous expression of the GDP-6-deoxy-D-lyxo-4-hexulose reductase (RMD). RMD catalyses the production of monosaccharide GDP-D-rhamnose which provides feedback inhibition to GMD activity ${ }^{68}$, resulting in less GDP-fucose production and lowered antibody fucosylation ${ }^{69}$. The introduction of heterologous RMD produced a surprisingly high (98\%) level of afucosylated IgG, reflecting the potency of this feedback inhibition pathway ${ }^{69}$. The technology based on this heterologous induction of RMD is referred to as GlymaxX developed by the company ProBioGen.

The above-mentioned glyco-engineering methods, notably carried out in $\mathrm{CHO}$ cells, produce the most mammalian-like IgG glycoforms comprising mostly biantennary complex type glycans. Oligosaccharides early in the N-glycosylation pathway intrinsically lack core fucose, as the $\alpha 1,6$-fucosyltransferase only acts from the midphase of the N-glycosylation pathway with the target glycans becoming more favoured substrates following the action of $\mathrm{GnTI}^{70}$. Therefore, retaining the oligosaccharide in its early immature form, prior to GnTI action, should enable the production of relatively homogenous afucosylated glycoforms. Indeed, the HEK293S cell line, which is engineered to be deficient in the GnTI enzyme required for oligosaccharide maturation, is commonly used to produce afucosylated oligomannose glycoforms ${ }^{71-72}$. However, despite homogeneous afucosylation, the predominance of the oligomannose antibody glycoforms produced deviates significantly in composition from the endogenous biantennary complex type glycoforms ${ }^{73}$, triggering debates over its perceived inferior in vivo pharmacokinetics ${ }^{74-76}$. On balance, it seems that oligomannose-type glycoforms of IgG do exhibit more rapid serum clearance presumably driven by lectin-mediated clearance pathways ${ }^{75}$. Nonetheless, this HEK293S cell line remains a useful glyco-engineering tool in the laboratory.

Besides mammalian cells, other eukaryotic systems have been engineered to produce low fucose antibodies. For example, the yeast Pichia pastoris has been extensively engineered to produce both homogeneous fucosylated and non-fucosylated glycoforms ${ }^{77}$. More recently, the unicellular ciliate, Tetrahymena thermophile, has been reported to generate highly afucoyslated mAbs with the advantageous ease of production ${ }^{78}$. Furthermore, the plant Lemna minor, when transfected with siRNA to supress its intrinsic $\alpha 1,3$-fucosyltransferase and $\beta 1,2$ xylosyltransferase activity, was able to generate $96 \%$ afucosylated, di-galactosylated glycoforms ${ }^{79}$. Notwithstanding the versatility of such non-mammalian systems, the existence of non-self carbohydrate epitopes, even in minute amount, has generally been considered a source of concern for their clinical use.

\subsection{Metabolic interference of host biosynthesis pathway}

Genetic modification of cellular systems usually requires significant investment, both temporal and financial. There are also substantial regulatory hurdles to pass before new cell lines are approved for the production of
Commented [Office1]: Note to typesetter: note L and D are "smallcaps". 
clinical grade material. Metabolic interference, which employs soluble enzyme inhibitors, potentially provides an alternative to the generation of new cell lines and is especially useful in preclinical laboratory settings where proof of concept takes priority. One molecule, kifunensine, an alkaloid inhibitor of the $\alpha 1,2$-mannosidase I enzyme, prevents the mannose trimming of the initial oligosaccharide and thus retains the $\mathrm{N}$-glycan in its early afucosylated oligomannose form ${ }^{80-81}$. Moreover, synthetic inhibitors (such as 2-fluorofucose) based on the structure of metabolic intermediates of the GDP-fucose de novo synthesis pathway were shown to elicit $95 \%$ afucosylated glycoforms in $\mathrm{CHO}$ cells ${ }^{82}$. However, compared with genetically modified host cell lines, inhibitor-based metabolic interference can prove impractical when production is scaled up for clinical use.

\subsection{Post-translational enzymatic modification}

An alternative strategy involves employing post-translational modification. Rapid advancement in chemical biology has expanded the set of synthetic tools available for post-translational glycan modification. In recent years, chemoenzymatic glyco-engineering has emerged as a reliable method for generating homogeneously glycosylated antibodies. In vitro enzymatic or chemoenzymatic glyco-engineering involves serial enzymatic treatments of purified antibodies to achieve the desired glycoform, which offers the potential to produce both diverse yet homogeneous glycoforms. For example, the serial treatment of IgG with recombinant galactosyltransferase and sialyltransferase coupled with their respective substrate is able to generate tetra-sialylated antibodies with an antiinflammatory effect ${ }^{41}$. However, much work still remains to do in this field as certain enzymatic reactions, such as defucosylation, within the $\mathrm{N}$-glycosylation pathway, cannot yet readily be reproduced in this manner on natively folded antibodies with the full biantennary complex glycans ${ }^{83}$.

Therefore, transglycosylation, a method in which the bulk Fc oligosaccharide is first removed followed by the addition of pre-synthesized glycans of the desired structure, was developed to bypass some inefficient glycosyltransferases and glycosidases in the N-glycosylation pathway. The first-generation transglycosylation was pioneered by the Wang group that uses EndoH to deglycosylate the bulk oligomannose Fc glycan, followed by the addition of synthetic small biantennary glycans back onto the same glycosylation site using the glycosyltransferase EndoA to generate fully afucosylated Fc glycoforms ${ }^{62}$. However, EndoA lacks the ability to transglycosylate the typical full length complex type glycans, which prompted the engineering of another bacterial glycosidase EndoS. EndoS usually deglycosylates Fc glycan but when mutated could be converted into a versatile Fc-specific trans-glycosyltranferase ${ }^{83}$. Indeed, the serial application of wild type EndoS to first remove the bulk Fc glycan and the fucosidase to remove any Fc core fucose, followed by the mutated EndoS (transglycosyltranferase) for the addition of fully afucosylated glycan, generated a human-like afucosylated Fc glycoform ${ }^{83}$. It is important that glycans pre-synthesized for transglycosylation in vitro do not undergo autocatalysis such as epimerization, which has been reported to contribute to heterogeneity ${ }^{84}$. Thus, chemoenzymatic glyco-engineering is an emerging route to generate fully afucosylated Fc glycoforms. However, this approach is likely to be advantageous over simple cell line or metabolic engineering mainly when particular synthetic challenges are faced, for example, when transglycosylation is employed to generate glycan-based antibody-drug conjugates ${ }^{85}$. Moreover, transglycosylation presents a significant challenge to cost-of-goods, and likely to be highly impractical as a manufacturing process unless it imparted critical functionality that could be obtained no other way. 


\section{Glyco-engineered antibodies in clinical oncology}

Most antibodies approved for cancer therapy have demonstrated, to various extents, components of ADCC or ADCP in their therapeutic efficacy. Afucosylated antibody glycoforms uniquely exhibit enhanced Fc engagement with the activatory Fc $\gamma$ RIIIa and Fc $\gamma$ RIIIb resulting in more potent ADCC and ADCP ${ }^{56-58}$. Since the first definitive report of defucosylation-mediated ADCC enhancement in the early $2000 \mathrm{~s}^{44}$, two glyco-engineered, afucosylated, mAbs have already been approved for cancer therapies ${ }^{86-87}$. A list of fucose-engineered antibodies developed for clinical oncology are shown in Table 1.

It is important to note that while fucose-engineered $\mathrm{mAbs}$ gained most attention for cancer indications, various glycan-engineered mAbs are also being developed for other diseases. For example, roledumab, a low fucose antiRhesus D mAb, is currently in phaseII/III clinical trial to combat the hemolytic disease of the fetus or newborn ${ }^{6}$,

${ }^{88}$. This section will focus on glyco-engineered antibodies for cancer treatment.

\subsection{Mogamulizumab, the first approved glyco-engineered $\mathrm{mAb}$}

As detailed above, Mogamulizumab, was the first approved (in Japan) glyco-engineered mAb for cancer therapy ${ }^{89}$. Generated through the Potelligent technology, it is an afucosylated therapeutic targeting the chemokine receptor CCR4. CCR4 is normally expressed on CD4+ Th2 cells and some other T cell subsets but is also abundant on most adult T cell leukaemia lymphoma (ATLL) and cutaneous T-cell lymphomas (CTCL) ${ }^{86,90}$. Mogamulizumab gained approval in 2012 for treatment of relapsed or refractory CCR4+ ATLL, and later in 2014 for treatment of relapsed or refractory CCR4+ CTCL ${ }^{86}$. Preclinical studies indicate that mogamulizumab acts only through ADCC or ADCP, as no CDC or direct cell death were observed ${ }^{91}$. Moreover, mogamulizumab engagement of CCR4 is claimed not to induce CCR4 internalization, which might contribute to its favourable pharmacokinetics ${ }^{92}$. In addition, while various in vitro assays demonstrate the dominance of ADCC in mediating mogamulizumab efficacy, a non-glyco-engineered counterpart was not examined for comparison ${ }^{91}$.

\subsection{Obinutuzumab and the anti-CD20 mAb family}

CD20 represents one of the most studied tumour targets with 5 of the 26 currently approved anti-cancer mAbs targeting this same receptor. The approval of the rituximab in 1997 transformed the treatment of NHL and CLL ${ }^{3}$, ${ }^{93}$, and paved the way for subsequent antibody therapeutics. Although various CD20-targeting mAbs followed suit into the clinic, the precise mechanism of action of anti-CD20 antibodies in the clinical setting remains debatable, partly due to the large amount of incongruous data generated over the years by different groups ${ }^{94}$. In preclinical studies, both Fc-mediated ADCC, ADCP, CDC and Fab-mediated direct cell death were evident for various anti$\mathrm{CD} 20 \mathrm{mAbs}^{94}$. The current consensus indicates that the Fc domain, and in particular host activatory Fc $\gamma \mathrm{Rs}$, are required to recapitulate the clinical efficacy of anti-CD20 ${ }^{12-13}$. The development of obinutuzumab, a low fucose anti-CD20 mAb approved in 2013 for treatment of CLL ${ }^{94}$ and in 2016 for rituximab relapsed/refractory follicular lymphoma (FL) ${ }^{95}$, was based on the premise that anti-CD20 mAb depletes malignant B cells through Fc $\gamma$ RIIIamediated ADCC and/or ADCP $96-98$. Conceived from the GlycoMab platform, obinutuzumab was shown to mediate superior ADCC using human peripheral blood mononuclear cells as effectors to target CD20-expressing cell lines compared with the non-glyco-engineered obinutuzumab variant (i.e. with predominantly fucosylated 
glycans), and rituximab, an observation recapitulated in xenograft tumour models ${ }^{97,99}$. Interestingly, the same study reported similar in vitro ADCP activity for all anti-CD20 mAbs examined regardless of the level of fucosylation ${ }^{56,99}$. In addition, obinutuzumab has been reported to exhibit increased neutrophil activation and phagocytosis through the neutrophil restricted activatory Fc $\gamma$ RIIIb compared to rituximab ${ }^{56}$. This is perhaps unsurprising as Fc $\gamma$ RIIIb is highly homologous to Fc $\gamma$ RIIIa. The two genes likely arose through a gene duplic ation event and, despite their similarity, differences in antibody binding affinity and cellular distribution may imply their differential immunological roles ${ }^{100}$.

In 2014, data from a large phase III trial concluded that obinutuzumab in combination with chlorambucil gave more complete responses and improved progression free and overall survival compared with rituximab plus chlorambucil in patients with untreated CLL and coexisting conditions ${ }^{87,101-102}$. Despite these conclusive clinical trial data, which many regard as a triumph for glyco-engineered anti-CD20 mAb therapy, questions remain over whether improvements conferred by obinutuzumab result from its low level of fucosylation, or from the fact that obinutuzumab is intrinsically a type II anti-CD20 mAb, a class of anti-CD20 antibodies associated with enhanced efficacy compared to type I anti-CD20 mAbs such as rituximab both in vitro and in multiple animal models ${ }^{94,103}$. Type I and type II anti-CD20 mAbs differ in their mode of CD20 engagement and are typically characterised by their ability to redistribute cell surface CD20 molecules to lipid rafts, among other differences ${ }^{97,}{ }^{104-105}$. More importantly, type II anti-CD20 mAbs are much less prone to internalization once bound to CD20 than type I mAbs, which are rapidly depleted from circulation ${ }^{99}$. This enhanced bioavailability of the type II obinutuzumab over the type I rituximab could contribute to the superiority of obinutuzumab in the trial, a hypothesis supported by a recent in vivo study demonstrating that the non-glyco-engineered, fucosylated form of obinutuzumab also outperforms rituximab in CLL clearance ${ }^{106}$.

\subsection{Trastuzumab}

Trastuzumab, commonly known as Herceptin, targets the Her2 molecule and was originally approved in 1998 for treatment of Her2 positive early stage breast cancer. Her 2 is a cell surface receptor with tyrosine kinase activity, whose overexpression leads to constitutive signalling for cell survival ${ }^{107}$. Like rituximab, its precise mechanism of action remains unresolved. Although early reports suggested that trastuzumab acts by disrupting Her2 downstream signalling leading to apoptosis ${ }^{108-109}$, recent studies implicate the importance of ADCC/ADCP in its efficacy ${ }^{110}$. The clinical implication of the Fc $\gamma$ R-mediated effector functions first emerged when one study found that patients treated with trastuzumab had better objective response rates when they possess the high affinity V/V $158 \mathrm{Fc} \gamma \mathrm{RIII}$ allotype compared with patients with the low affinity F/F or mixed V/F allotypes ${ }^{111}$. Consistently, PMBCs isolated from patients with the high affinity V/V 158 allotype exhibit enhanced ADCC against Her2 positive human breast cancer cell lines ${ }^{111}$. On the other hand, genetic polymorphisms within the Fc $\gamma$ RIIB or Fc $\gamma$ RIIA were not found to influence therapeutic outcomes ${ }^{111}$. This apparent association of superior therapeutic efficacy with high affinity Fc $\gamma$ RIIIa engagement warrants Fc-engineering to further improve trastuzumab activity. Indeed, an afucosylated version of trastuzumab was produced using the FUT8 KO CHO cell line, which exhibits an 11-fold enhancement in ADCC against the Her2-amplified BT474-M1 cell line compared with its non-glycoengineered parent ${ }^{112}$. Furthermore, afucosylated trastuzumab significantly improved the survival of tumourxenografted animals transgenic for the human Fc $\gamma$ RIIIa compared with the non-glyco-engineered trastuzumab, an effect lost when the hFc $\gamma$ RIIIa is absent, further demonstrating the superior efficacy of an afucosylated 
trastuzumab ${ }^{112}$. The enhanced ADCC observed in vitro and survival benefits in animal models warrant the continued clinical development of an afucosylated trastuzumab.

\subsection{Afucosylated anti-EGFR GA201}

EGFR is a receptor tyrosine kinase whose expression and activation are upregulated in diverse epithelial cancers. The anti-EGFR mAbs, cetuximab and panitumumab, represent established treatments for colorectal cancer and head and neck cancer, respectively; however, the overall response rate and survival benefits remain modest, with patients possessing KRAS mutations (of which a large proportion of these patients do) remaining unresponsive 113-114. Although anti-EGFR mAbs are purported to function through EGFR signalling blockade ${ }^{115}$, it was hypothesized that their modest clinical efficacy might benefit from an engineered Fc. The low fucose anti-EGFR mAb GA201 was therefore generated using the GlycoMab technology and shown to be approximately $85 \%$ afucosylated ${ }^{116}$. In vitro assays demonstrated that GA201 inhibits EGFR signal transduction to similar extent as cetuximab; however, afucosylation boosted the ADCC activity of GA201 significantly above that of cetux imab or the non-glyco-engineered GA201 ${ }^{116}$. More importantly, GA201 exhibited ADCC activity towards tumour cell lines with KRAS mutations ${ }^{116}$. The in vitro efficacy was recapitulated in xenograft animal models in which GA201 treatment led to prolonged survival compared with cetuximab regardless of the tumour KRAS mutation status ${ }^{116}$. A phase I clinical trial also gave early demonstration of GA201 activity in EGFR positive solid tumours, including patients with KRAS mutations ${ }^{117}$. Interestingly, Fc $\gamma$ RIIIa polymorphism status did not influence the activity of GA201 in these patients, in contrast to those involved in the trastuzumab trial discussed earlier ${ }^{111,117}$, potentially indicating that the glyco-engineering overcomes the lower activity associated with the low affinity allele, although this requires further confirmatory study in larger cohorts to confirm.

\subsection{Anti-EphA3}

Similar to EGFR, EphA3 is a receptor tyrosine kinase belonging to the family of Eph receptor tyrosine kinases involved in the regulation of cell-cell communication and development ${ }^{118}$. Although there is no current antiEphA3 mAb approved or indeed in late phase development, recently an afucosylated anti-EphA3 mAb, KB004, was reported to demonstrate modest efficacy in a phase I trial of relapsed and/or refractory hematologic malignancies ${ }^{119-120}$. The mechanism of action of KB004 remains unknown but presumably reflects those described above for EGFR mAbs.

\subsection{Anti-CD19}

CD19 is a ubiquitous marker expressed on B cells that associates with the BCR and acts to promote B cell activation. Due to its widespread expression on B cells, including early progenitors, CD19 has been assessed as a target for numerous B cell malignancies spanning ALL, CLL and NHL ${ }^{121}$. Despite ubiquitous antigen expression, the efficacy of the conventional anti-CD19 mAbs developed so far indicates an inferiority to their anti-CD20 counterparts, with a notable lack of durable responses ${ }^{122-123}$. Given their disappointing responses to date, antibody engineering has been attempted on these mAb to boost activity. To date, the only approved CD19targeting biological therapeutic remains a bispecific anti-CD19/CD3 comprising two scFv chains, which acts to recruit $\mathrm{CD} 3$ positive $\mathrm{T}$ cells to exert cytotoxicity against $\mathrm{B}$ cells ${ }^{121}$. In addition, multiple afucosylated anti-CD19 mAbs have been generated and are being clinically assessed. For example, MDX-1342, produced using the Potelligent technology, exhibits both enhanced ADCC and ADCP compared with its non-glyco-engineered 
version, and was able to mediate a higher level of B cell depletion in non-human primates ${ }^{124-125}$. A phase I trial of MDX-1342 to treat CD19-positive relapsed or refractory CLL demonstrated partial response in one of the nine patients recruited ${ }^{126-127}$. MEDI-551 is another afucosylated anti-CD19 mAb, which similar to MDX-1342, exhibits more potent ADCC in vitro than its non-glyco-engineered parent as well as efficacy in multiple xenograft animal models ${ }^{125,128}$. In a phase I/II clinical trial in patients with relapsed or refractory FL, diffuse large B-cell lymphoma, CLL, or multiple myeloma, MEDI-551 demonstrated moderate activity as a monotherapy ${ }^{129-130}$. A third afucosylated mAb, DI-B4, has been transferred from Merck to Cancer Research UK as part of its Clinical Development Partnerships (CDP) programme, has recently been the subject of a Phase I trial in CD19 positive indolent B-cell lymphoma. No clinical results have been released yet.

\subsection{Anti-CD30}

CD30 belongs to the TNFR family involved in the regulation of cell survival. Its expression in normal tissues is restricted to activated $\mathrm{B}$ cells and $\mathrm{T}$ cells but it is highly expressed on $\mathrm{T}$ cell-derived tumours including anaplastic large-cell lymphoma and cutaneous T-cell lymphoma, making it a favourable tumour marker ${ }^{131}$. Currently the only approved CD30-targeting antibody is Brentuximab Vedotin, an antibody-drug conjugate, whose efficacy stems from the cytotoxic agent monomethyl auristatin $\mathrm{E}^{132}$. One anti-CD30 mAb, MDX-60, demonstrated modest efficacy against Hodgkin's lymphoma and anaplastic large-cell lymphoma in a phase I/II trial ${ }^{133}$. Its afucosylated version, MDX-1401, was subsequently developed using the Potelligent technology and improved survival in a xenograft animal model ${ }^{134}$. Moreover, in a phase I trial involving twelve refractory or relapsed HL patients, MDX1401 treatment led to a reduction in tumour burden for patients experiencing stable disease ${ }^{135}$.

\subsection{Anti-CD40}

Like CD30, CD40 is a member of the TNFR family and has been extensively explored as a target for immunotherapy and anti-inflammatory applications ${ }^{9,136}$. CD40 is ubiquitously expressed on various immune cells including B cells, macrophages, dendritic cells, as well as non-immune cells such as platelets and endothelial cells 137. Although immunomodulatory (agonistic) anti-CD40 mAbs dominate the current focus for cancer research ${ }^{9}$, some anti-CD40 mAbs were developed to target CD40-expressing B cell lymphomas as direct targeting mAbs: aiming to block positive signalling from, or even mediate inhibitory signalling through, CD40; or to mediate Fcdependent cellular destruction. Currently, only one anti-CD40 mAb, SEA-CD40, has been developed as an afucosylated therapeutic directed at CD40, which exhibits enhanced ADCC in vitro compared with its fucosylated parent SGN40 ${ }^{138-139}$. The development of SEA-CD40, however, is at odds with the apparent mechanism of action of its parent antibody, SGN40. SGN40 demonstrates modest clinical activity in CLL and diffuse large B-cell lymphoma ${ }^{140-141}$, but its in vivo efficacy, at least in one xenograft animal model, does not appear to require NK cell-mediated ADCC but rather depends on Fab-mediated apoptosis as full activity was demonstrated in mice lacking NK cells ${ }^{142}$. Consistently, the clinical activity of SGN40 demonstrated in a phase II trial indicates a lack of correlation between patient Fc $\gamma$ RIIIa $158 \mathrm{~V} / \mathrm{F}$ polymorphism and therapeutic activity ${ }^{140}$. Nevertheless, the enhanced engagement between an afucosylated $\mathrm{mAb}$ and the Fc $\gamma \mathrm{RIII}$ a provides the potential to overcome the in vivo threshold for SGN40-mediated ADCC and offer synergy with Fab-mediated apoptosis.

\subsection{Anti-B-cell maturation antigen (BCMA)}


The BCMA gene was originally identified from a translocation event in malignant $\mathrm{T}$ cell lymphoma patient and was later found to be preferentially expressed on mature B cells ${ }^{143-144}$. It has since been established to be a member of the TNF receptor superfamily that interacts with B cell activating factor (BAFF) and a proliferation-inducing ligand (APRIL) involved in B cell survival ${ }^{145-146}$. The ubiquitous expression of BCMA on multiple myeloma (MM) cells, but not on other normal human cell populations and tissues, renders BCMA a direct target for MM 147-148. The first low fucose anti-BCMA mAb J6M0, humanized from a murine parent and fucose-engineered using the Potelligent platform, had an additional functional feature whereby the cytotoxic drug monomethyl auristatin (MMA), a synthetic inhibitor of cell division, is conjugated to its Fc domain ${ }^{148}$. The Fc domain of such a low fucose antibody-drug conjugate (ADC) would be expected to not only induce enhanced cellular effector function via FcyRIIIA but also exert direct toxicity towards target tumor cells. Consistent with this hypothesis, J6M0MMA mediated efficient in vitro phagocytosis of MM cells by macrophages and reduced the MM cell viability independent of immune effectors ${ }^{148}$. Using immune-compromised animal models, the same group also reported superior in vivo efficacy of J6M0-MMA against human MM cell lines, compared with J6M0 alone ${ }^{148}$. Nevertheless, the murine parent of J6M0 was not included in these experiments for comparison. While the MMA was covalently conjugated to the Fc protein backbone of J6M0, it is notable that with the coming of age of ADC, the unique chemistry of antibody Fc glycan (as opposed to the amino acid backbone) has been increasingly exploited as a site for cytotoxic drug conjugation ${ }^{149-155}$. The marriage between the intrinsic immune-modulatory properties of Fc glycan and its differential chemistry (from protein backbone) could prove to be a game-changing next generation cancer therapeutics.

\section{Conclusion}

In summary, it is clear that we are now entering an era when non-canonical antibody therapeutics are becoming commonplace. With recent advances in glyco-engineering we possess the tools to fine-tune the ability of the $\mathrm{Fc}$ to elicit the desired interactions with its potential receptors and interaction partners. The developments in afucosylation demonstrate a proof-of-principle that we can manipulate these interactions to elicit more efficacious responses from certain cellular effectors, potentially overcoming inter-patient variabilities in sub-optimal Fc $\gamma \mathrm{R}$ genotypes. However, the clinical experience illustrates that it is more important than ever that we fully understand the mechanisms of action of the parental mAbs in vivo before we undertake such studies - only then will the full potential of glyco-engineering be realised for patients.

\section{Conflicts of Interest}

MC is supported by a research grant from Against Breast Cancer (www.againstbreastcancer.org; UK charity number 1121258) and is the Against Breast Cancer Fellow at Oriel College, Oxford. MC was 
founder and director of Immago Biosystems which was acquired by Hansa Medical. MM is supported by a BBSRC iCASE studentship in partnership with Roche. MSC acts as a consultant for Bioinvent International and has previously received research grant support from Roche, UCB and Promega, and has received honorarium from Baxalta. XY declares no conflicts of interest. No additional funding was received for the preparation of this review.

\section{References}

1. Maloney, D. G.; Grillo-Lopez, A. J.; White, C. A.; Bodkin, D.; Schilder, R. J.; Neidhart, J. A.; Janakiraman, N.; Foon, K. A.; Liles, T. M.; Dallaire, B. K.; Wey, K.; Royston, I.; Davis, T.; Levy, R., IDECC2B8 (Rituximab) anti-CD20 monoclonal antibody therapy in patients with relapsed low-grade nonHodgkin's lymphoma. Blood 1997, 90 (6), 2188-95.

2. Casak, S. J.; Lemery, S. J.; Shen, Y. L.; Rothmann, M. D.; Khandelwal, A.; Zhao, H.; Davis, G.; Jarral, V.; Keegan, P.; Pazdur, R., U.S. Food and drug administration approval: rituximab in combination with fludarabine and cyclophosphamide for the treatment of patients with chronic lymphocytic leukemia. Oncologist 2011, 16 (1), 97-104.

3. Molina, A., A decade of rituximab: improving survival outcomes in non-Hodgkin's lymphoma. Annu Rev Med 2008, 59, 237-50.

4. Scott, A. M.; Wolchok, J. D.; Old, L. J., Antibody therapy of cancer. Nat Rev Cancer 2012, 12 (4), 278-87.

5. Guan, M.; Zhou, Y. P.; Sun, J. L.; Chen, S. C., Adverse events of monoclonal antibodies used for cancer therapy. Biomed Res Int 2015, 2015, 428169.

6. Reichert, J. M., Antibodies to watch in 2017. MAbs 2016, 1-15.

7. Nimmerjahn, F.; Gordan, S.; Lux, A., FcgammaR dependent mechanisms of cytotoxic, agonistic, and neutralizing antibody activities. Trends Immunol 2015, 36 (6), 325-36.

8. Lee, C. S.; Cragg, M.; Glennie, M.; Johnson, P., Novel antibodies targeting immune regulatory checkpoints for cancer therapy. Br J Clin Pharmacol 2013, 76 (2), 233-47.

9. Vonderheide, R. H.; Glennie, M. J., Agonistic CD40 antibodies and cancer therapy. Clin Cancer Res 2013, 19 (5), 1035-43.

10. Berman, D.; Korman, A.; Peck, R.; Feltquate, D.; Lonberg, N.; Canetta, R., The development of immunomodulatory monoclonal antibodies as a new therapeutic modality for cancer: The BristolMyers Squibb experience. Pharmacol Therapeut 2015, 148, 132-153.

11. Hodi, F. S.; O'Day, S. J.; McDermott, D. F.; Weber, R. W.; Sosman, J. A.; Haanen, J. B.; Gonzalez, R.; Robert, C.; Schadendorf, D.; Hassel, J. C.; Akerley, W.; van den Eertwegh, A. J.; Lutzky, J.; Lorigan, P.; Vaubel, J. M.; Linette, G. P.; Hogg, D.; Ottensmeier, C. H.; Lebbe, C.; Peschel, C.; Quirt, I.; Clark, J. I.; Wolchok, J. D.; Weber, J. S.; Tian, J.; Yellin, M. J.; Nichol, G. M.; Hoos, A.; Urba, W. J., Improved survival with ipilimumab in patients with metastatic melanoma. N Engl J Med 2010, 363 (8), 711-23.

12. Clynes, R. A.; Towers, T. L.; Presta, L. G.; Ravetch, J. V., Inhibitory Fc receptors modulate in vivo cytotoxicity against tumor targets. Nature medicine 2000, 6 (4), 443-6.

13. Uchida, J.; Hamaguchi, Y.; Oliver, J. A.; Ravetch, J. V.; Poe, J. C.; Haas, K. M.; Tedder, T. F., The innate mononuclear phagocyte network depletes B lymphocytes through $\mathrm{Fc}$ receptor-dependent mechanisms during anti-CD20 antibody immunotherapy. The Journal of experimental medicine 2004, 199 (12), 1659-69.

14. White, A. L.; Chan, H. T.; Roghanian, A.; French, R. R.; Mockridge, C. I.; Tutt, A. L.; Dixon, S. V.; Ajona, D.; Verbeek, J. S.; Al-Shamkhani, A.; Cragg, M. S.; Beers, S. A.; Glennie, M. J., Interaction with FcgammaRIIB is critical for the agonistic activity of anti-CD40 monoclonal antibody. J Immunol 2011, $187(4), 1754-63$. 
15. White, A. L.; Chan, H. T.; French, R. R.; Willoughby, J.; Mockridge, C. I.; Roghanian, A.; Penfold, C. A.; Booth, S. G.; Dodhy, A.; Polak, M. E.; Potter, E. A.; Ardern-Jones, M. R.; Verbeek, J. S.; Johnson, P. W.; Al-Shamkhani, A.; Cragg, M. S.; Beers, S. A.; Glennie, M. J., Conformation of the human immunoglobulin g2 hinge imparts superagonistic properties to immunostimulatory anticancer antibodies. Cancer cell 2015, 27 (1), 138-48.

16. Mekhaiel, D. N. A.; Czajkowsky, D. M.; Andersen, J. T.; Shi, J.; El-Faham, M.; Doenhoff, M.; McIntosh, R. S.; Sandlie, I.; He, J.; Hu, J.; Shao, Z.; Pleass, R. J., Polymeric human Fc-fusion proteins with modified effector functions. Scientific Reports 2011, 1 (124).

17. Roghanian, A.; Teige, I.; Martensson, L.; Cox, K. L.; Kovacek, M.; Ljungars, A.; Mattson, J.; Sundberg, A.; Vaughan, A. T.; Shah, V.; Smyth, N. R.; Sheth, B.; Chan, H. T.; Li, Z. C.; Williams, E. L.; Manfredi, G.; Oldham, R. J.; Mockridge, C. I.; James, S. A.; Dahal, L. N.; Hussain, K.; Nilsson, B.; Verbeek, J. S.; Juliusson, G.; Hansson, M.; Jerkeman, M.; Johnson, P. W.; Davies, A.; Beers, S. A.; Glennie, M. J.; Frendeus, B.; Cragg, M. S., Antagonistic human FcgammaRIIB (CD32B) antibodies have anti-tumor activity and overcome resistance to antibody therapy in vivo. Cancer cell 2015, 27 (4), 473-88.

18. Li, F.; Ravetch, J. V., Inhibitory Fcgamma receptor engagement drives adjuvant and anti-tumor activities of agonistic CD40 antibodies. Science 2011, 333 (6045), 1030-4.

19. Lux, A.; Nimmerjahn, F., No Need for Constant Help: Human IgG2 Antibodies Have an Autonomous Agonistic Activity for Immunotherapy of Cancer. Cancer cell 2015, 27 (1), 10-11.

20. Wilson, N. S.; Yang, B.; Yang, A.; Loeser, S.; Marsters, S.; Lawrence, D.; Li, Y.; Pitti, R.; Totpal, K.; Yee, S.; Ross, S.; Vernes, J. M.; Lu, Y.; Adams, C.; Offringa, R.; Kelley, B.; Hymowitz, S.; Daniel, D.; Meng, G.; Ashkenazi, A., An Fcgamma receptor-dependent mechanism drives antibody-mediated target-receptor signaling in cancer cells. Cancer cell 2011, 19 (1), 101-13.

21. Anderson, C. L.; Ganesan, L. P.; Robinson, J. M., The biology of the classical Fcgamma receptors in non-hematopoietic cells. Immunol Rev 2015, 268 (1), 236-40.

22. Nimmerjahn, F.; Ravetch, J. V., Fcgamma receptors as regulators of immune responses. Nat Rev Immunol 2008, 8 (1), 34-47.

23. Unkeless, J. C.; Jin, J., Inhibitory receptors, ITIM sequences and phosphatases. Curr Opin Immunol 1997, 9 (3), 338-43.

24. Daeron, M., Fc receptor biology. Annu Rev Immunol 1997, 15, 203-34.

25. Bruhns, P., Properties of mouse and human IgG receptors and their contribution to disease models. Blood 2012, 119 (24), 5640-9.

26. Dahal, L. N.; Roghanian, A.; Beers, S. A.; Cragg, M. S., Fc gamma R requirements leading to successful immunotherapy. Immunological Reviews 2015, 268 (1), 104-122.

27. Wu, J.; Edberg, J. C.; Redecha, P. B.; Bansal, V.; Guyre, P. M.; Coleman, K.; Salmon, J. E.; Kimberly, R. P., A novel polymorphism of FcgammaRIlla (CD16) alters receptor function and predisposes to autoimmune disease. J Clin Invest 1997, 100 (5), 1059-70.

28. Cartron, G.; Dacheux, L.; Salles, G.; Solal-Celigny, P.; Bardos, P.; Colombat, P.; Watier, H., Therapeutic activity of humanized anti-CD20 monoclonal antibody and polymorphism in IgG Fc receptor FcgammaRIlla gene. Blood 2002, 99 (3), 754-8.

29. Shields, R. L.; Namenuk, A. K.; Hong, K.; Meng, Y. G.; Rae, J.; Briggs, J.; Xie, D.; Lai, J.; Stadlen, A.; Li, B.; Fox, J. A.; Presta, L. G., High resolution mapping of the binding site on human IgG1 for Fc gamma RI, Fc gamma RII, Fc gamma RIII, and FcRn and design of IgG1 variants with improved binding to the Fc gamma R. J Biol Chem 2001, 276 (9), 6591-604.

30. Preithner, S.; Elm, S.; Lippold, S.; Locher, M.; Wolf, A.; da Silva, A. J.; Baeuerle, P. A.; Prang, N. S., High concentrations of therapeutic IgG1 antibodies are needed to compensate for inhibition of antibody-dependent cellular cytotoxicity by excess endogenous immunoglobulin G. Molecular immunology 2006, 43 (8), 1183-93.

31. Baruah, K.; Bowden, T. A.; Krishna, B. A.; Dwek, R. A.; Crispin, M.; Scanlan, C. N., Selective deactivation of serum IgG: a general strategy for the enhancement of monoclonal antibody receptor interactions. J Mol Biol 2012, 420 (1-2), 1-7. 
32. Arnold, J. N.; Wormald, M. R.; Sim, R. B.; Rudd, P. M.; Dwek, R. A., The impact of glycosylation on the biological function and structure of human immunoglobulins. Annu Rev Immunol 2007, 25, 21-

50 .

33. Lund, J.; Takahashi, N.; Pound, J. D.; Goodall, M.; Jefferis, R., Multiple interactions of IgG with its core oligosaccharide can modulate recognition by complement and human Fc gamma receptor I and influence the synthesis of its oligosaccharide chains. J Immunol 1996, 157 (11), 4963-9.

34. Walker, M. R.; Lund, J.; Thompson, K. M.; Jefferis, R., Aglycosylation of Human Igg1 and Igg3 Monoclonal-Antibodies Can Eliminate Recognition by Human-Cells Expressing Fc-Gamma-Ri and or FcGamma-Rii Receptors. Biochem J 1989, 259 (2), 347-353.

35. Jefferis, R.; Lund, J., Glycosylation of antibody molecules: structural and functional significance. Chem Immunol 1997, 65, 111-28.

36. Malhotra, R.; Wormald, M. R.; Rudd, P. M.; Fischer, P. B.; Dwek, R. A.; Sim, R. B., Glycosylation changes of IgG associated with rheumatoid arthritis can activate complement via the mannosebinding protein. Nature medicine 1995, 1 (3), 237-43.

37. Rook, G. A.; Steele, J.; Brealey, R.; Whyte, A.; Isenberg, D.; Sumar, N.; Nelson, J. L.; Bodman, K. B.; Young, A.; Roitt, I. M.; et al., Changes in IgG glycoform levels are associated with remission of arthritis during pregnancy. Journal of autoimmunity 1991, 4 (5), 779-94.

38. Alavi, A.; Arden, N.; Spector, T. D.; Axford, J. S., Immunoglobulin G glycosylation and clinical outcome in rheumatoid arthritis during pregnancy. J Rheumatol 2000, 27 (6), 1379-85.

39. van de Geijn, F. E.; Wuhrer, M.; Selman, M. H.; Willemsen, S. P.; de Man, Y. A.; Deelder, A. M.; Hazes, J. M.; Dolhain, R. J., Immunoglobulin G galactosylation and sialylation are associated with pregnancy-induced improvement of rheumatoid arthritis and the postpartum flare: results from a large prospective cohort study. Arthritis research \& therapy 2009, 11 (6), R193.

40. Ackerman, M. E.; Crispin, M.; Yu, X.; Baruah, K.; Boesch, A. W.; Harvey, D. J.; Dugast, A. S.; Heizen, E. L.; Ercan, A.; Choi, I.; Streeck, H.; Nigrovic, P. A.; Bailey-Kellogg, C.; Scanlan, C.; Alter, G., Natural variation in Fc glycosylation of HIV-specific antibodies impacts antiviral activity. J Clin Invest 2013, 123 (5), 2183-92.

41. Washburn, N.; Schwab, I.; Ortiz, D.; Bhatnagar, N.; Lansing, J. C.; Medeiros, A.; Tyler, S.; Mekala, D.; Cochran, E.; Sarvaiya, H.; Garofalo, K.; Meccariello, R.; Meador, J. W., 3rd; Rutitzky, L.; Schultes, B. C.; Ling, L.; Avery, W.; Nimmerjahn, F.; Manning, A. M.; Kaundinya, G. V.; Bosques, C. J., Controlled tetra-Fc sialylation of IVIg results in a drug candidate with consistent enhanced anti-inflammatory activity. Proc Natl Acad Sci U S A 2015, 112 (11), E1297-306.

42. Kaneko, Y.; Nimmerjahn, F.; Ravetch, J. V., Anti-inflammatory activity of immunoglobulin G resulting from Fc sialylation. Science 2006, 313 (5787), 670-3.

43. Li, T.; DiLillo, D. J.; Bournazos, S.; Giddens, J. P.; Ravetch, J. V.; Wang, L. X., Modulating IgG effector function by Fc glycan engineering. Proc Natl Acad Sci U S A 2017, 114 (13), 3485-3490.

44. Shields, R. L.; Lai, J.; Keck, R.; O'Connell, L. Y.; Hong, K.; Meng, Y. G.; Weikert, S. H.; Presta, L. G., Lack of fucose on human IgG1 N-linked oligosaccharide improves binding to human Fcgamma RIII and antibody-dependent cellular toxicity. J Biol Chem 2002, 277 (30), 26733-40.

45. Shinkawa, T.; Nakamura, K.; Yamane, N.; Shoji-Hosaka, E.; Kanda, Y.; Sakurada, M.; Uchida, K.; Anazawa, H.; Satoh, M.; Yamasaki, M.; Hanai, N.; Shitara, K., The absence of fucose but not the presence of galactose or bisecting $\mathrm{N}$-acetylglucosamine of human IgG1 complex-type oligosaccharides shows the critical role of enhancing antibody-dependent cellular cytotoxicity. J Biol Chem 2003, 278 (5), 3466-73.

46. Niwa, R.; Natsume, A.; Uehara, A.; Wakitani, M.; lida, S.; Uchida, K.; Satoh, M.; Shitara, K., IgG subclass-independent improvement of antibody-dependent cellular cytotoxicity by fucose removal from Asn297-linked oligosaccharides. J Immunol Methods 2005, 306 (1-2), 151-60.

47. Kanda, Y.; Yamane-Ohnuki, N.; Sakai, N.; Yamano, K.; Nakano, R.; Inoue, M.; Misaka, H.; lida, S.; Wakitani, M.; Konno, Y.; Yano, K.; Shitara, K.; Hosoi, S.; Satoh, M., Comparison of cell lines for stable production of fucose-negative antibodies with enhanced ADCC. Biotechnology and bioengineering 2006, 94 (4), 680-8. 
48. Ferrara, C.; Grau, S.; Jäger, C.; Sondermann, P.; Brünker, P.; Waldhauer, I.; Hennig, M.; Ruf, A.; Rufer, A. C.; Stihle, M.; Umaña, P.; Benz, J., Unique carbohydrate-carbohydrate interactions are required for high affinity binding between FcyRIII and antibodies lacking core fucose. Proceedings of the National Academy of Sciences 2011, 108 (31), 12669-12674.

49. Mizushima, T.; Yagi, H.; Takemoto, E.; Shibata-Koyama, M.; Isoda, Y.; lida, S.; Masuda, K.; Satoh, M.; Kato, K., Structural basis for improved efficacy of therapeutic antibodies on defucosylation of their Fc glycans. Genes Cells 2011, 16 (11), 1071-80.

50. Giulino, L. B.; Bussel, J. B.; Neufeld, E. J.; Pediatric; Platelet Immunology Committees of the, T. M. H. C. T. N., Treatment with rituximab in benign and malignant hematologic disorders in children. J Pediatr 2007, 150 (4), 338-44, 344 e1.

51. Hosono, M.; Endo, K.; Sakahara, H.; Watanabe, Y.; Saga, T.; Nakai, T.; Kawai, C.; Matsumori, A.; Yamada, T.; Watanabe, T.; Konishi, J., Human Mouse Chimeric Antibodies Show Low Reactivity with Human Antimurine Antibodies (Hama). Brit J Cancer 1992, 65 (2), 197-200.

52. Sheeley, D. M.; Merrill, B. M.; Taylor, L. C., Characterization of monoclonal antibody glycosylation: comparison of expression systems and identification of terminal alpha-linked galactose. Analytical biochemistry 1997, 247 (1), 102-10.

53. Qian, J.; Liu, T.; Yang, L.; Daus, A.; Crowley, R.; Zhou, Q., Structural characterization of N-linked oligosaccharides on monoclonal antibody cetuximab by the combination of orthogonal matrixassisted laser desorption/ionization hybrid quadrupole-quadrupole time-of-flight tandem mass spectrometry and sequential enzymatic digestion. Analytical biochemistry 2007, 364 (1), 8-18.

54. Galili, U.; Rachmilewitz, E. A.; Peleg, A.; Flechner, I., A unique natural human IgG antibody with anti-alpha-galactosyl specificity. The Journal of experimental medicine 1984, 160 (5), 1519-31.

55. Chung, C. H.; Mirakhur, B.; Chan, E.; Le, Q. T.; Berlin, J.; Morse, M.; Murphy, B. A.; Satinover, S. M.; Hosen, J.; Mauro, D.; Slebos, R. J.; Zhou, Q.; Gold, D.; Hatley, T.; Hicklin, D. J.; Platts-Mills, T. A., Cetuximab-induced anaphylaxis and IgE specific for galactose-alpha-1,3-galactose. N Engl J Med 2008, 358 (11), 1109-17.

56. Golay, J.; Da Roit, F.; Bologna, L.; Ferrara, C.; Leusen, J. H.; Rambaldi, A.; Klein, C.; Introna, M., Glycoengineered CD20 antibody obinutuzumab activates neutrophils and mediates phagocytosis through CD16B more efficiently than rituximab. Blood 2013, 122 (20), 3482-3491.

57. Herter, S.; Birk, M. C.; Klein, C.; Gerdes, C.; Umana, P.; Bacac, M., Glycoengineering of Therapeutic Antibodies Enhances Monocyte/Macrophage-Mediated Phagocytosis and Cytotoxicity. Journal of Immunology 2014, 192 (5), 2252-2260.

58. Umana, P.; Jean-Mairet, J.; Moudry, R.; Amstutz, H.; Bailey, J. E., Engineered glycoforms of an antineuroblastoma IgG1 with optimized antibody-dependent cellular cytotoxic activity. Nat Biotechnol 1999, $17(2), 176-80$.

59. Evans, J. B.; Syed, B. A., From the analyst's couch: Next-generation antibodies. Nat Rev Drug Discov 2014, 13 (6), 413-4.

60. Schachter, H., Biosynthetic controls that determine the branching and microheterogeneity of protein-bound oligosaccharides. Biochem Cell Biol 1986, 64 (3), 163-81.

61. Ferrara, C.; Brunker, P.; Suter, T.; Moser, S.; Puntener, U.; Umana, P., Modulation of therapeutic antibody effector functions by glycosylation engineering: influence of Golgi enzyme localization domain and co-expression of heterologous beta1, 4-N-acetylglucosaminyltransferase III and Golgi alpha-mannosidase II. Biotechnology and bioengineering 2006, 93 (5), 851-61.

62. Zou, G.; Ochiai, H.; Huang, W.; Yang, Q.; Li, C.; Wang, L. X., Chemoenzymatic synthesis and Fcgamma receptor binding of homogeneous glycoforms of antibody Fc domain. Presence of a bisecting sugar moiety enhances the affinity of Fc to Fcgammallla receptor. Journal of the American Chemical Society 2011, 133 (46), 18975-91.

63. Yamane-Ohnuki, N.; Kinoshita, S.; Inoue-Urakubo, M.; Kusunoki, M.; lida, S.; Nakano, R.; Wakitani, M.; Niwa, R.; Sakurada, M.; Uchida, K.; Shitara, K.; Satoh, M., Establishment of FUT8 knockout Chinese hamster ovary cells: an ideal host cell line for producing completely defucosylated 
antibodies with enhanced antibody-dependent cellular cytotoxicity. Biotechnology and bioengineering 2004, 87 (5), 614-22.

64. Matsushita, T., Engineered therapeutic antibodies with enhanced effector functions: Clinical application of the Potelligent(R) Technology. Korean J Hematol 2011, 46 (3), 148-50.

65. Mori, K.; Kuni-Kamochi, R.; Yamane-Ohnuki, N.; Wakitani, M.; Yamano, K.; Imai, H.; Kanda, Y.; Niwa, R.; lida, S.; Uchida, K.; Shitara, K.; Satoh, M., Engineering Chinese hamster ovary cells to maximize effector function of produced antibodies using FUT8 siRNA. Biotechnology and bioengineering 2004, 88 (7), 901-8.

66. Sullivan, F. X.; Kumar, R.; Kriz, R.; Stahl, M.; Xu, G. Y.; Rouse, J.; Chang, X. J.; Boodhoo, A.; Potvin, B.; Cumming, D. A., Molecular cloning of human GDP-mannose 4,6-dehydratase and reconstitution of GDP-fucose biosynthesis in vitro. J Biol Chem 1998, 273 (14), 8193-202.

67. Kanda, Y.; Imai-Nishiya, H.; Kuni-Kamochi, R.; Mori, K.; Inoue, M.; Kitajima-Miyama, K.; Okazaki, A.; lida, S.; Shitara, K.; Satoh, M., Establishment of a GDP-mannose 4,6-dehydratase (GMD) knockout host cell line: a new strategy for generating completely non-fucosylated recombinant therapeutics. $J$ Biotechnol 2007, 130 (3), 300-10.

68. King, J. D.; Poon, K. K.; Webb, N. A.; Anderson, E. M.; McNally, D. J.; Brisson, J. R.; Messner, P.; Garavito, R. M.; Lam, J. S., The structural basis for catalytic function of GMD and RMD, two closely related enzymes from the GDP-D-rhamnose biosynthesis pathway. FEBS J 2009, 276 (10), 2686-700.

69. von Horsten, H. H.; Ogorek, C.; Blanchard, V.; Demmler, C.; Giese, C.; Winkler, K.; Kaup, M.; Berger, M.; Jordan, I.; Sandig, V., Production of non-fucosylated antibodies by co-expression of heterologous GDP-6-deoxy-D-lyxo-4-hexulose reductase. Glycobiology 2010, 20 (12), 1607-18.

70. Crispin, M.; Harvey, D. J.; Chang, V. T.; Yu, C.; Aricescu, A. R.; Jones, E. Y.; Davis, S. J.; Dwek, R. A.; Rudd, P. M., Inhibition of hybrid- and complex-type glycosylation reveals the presence of the GlcNAc transferase I-independent fucosylation pathway. Glycobiology 2006, 16 (8), 748-56.

71. Reeves, P. J.; Callewaert, N.; Contreras, R.; Khorana, H. G., Structure and function in rhodopsin: high-level expression of rhodopsin with restricted and homogeneous $\mathrm{N}$-glycosylation by a tetracyclineinducible N-acetylglucosaminyltransferase I-negative HEK293S stable mammalian cell line. Proc Natl Acad Sci U S A 2002, 99 (21), 13419-24.

72. Yu, X.; Baruah, K.; Harvey, D. J.; Vasiljevic, S.; Alonzi, D. S.; Song, B. D.; Higgins, M. K.; Bowden, T. A.; Scanlan, C. N.; Crispin, M., Engineering hydrophobic protein-carbohydrate interactions to finetune monoclonal antibodies. Journal of the American Chemical Society 2013, 135 (26), 9723-32.

73. Yu, X.; Vasiljevic, S.; Mitchell, D. A.; Crispin, M.; Scanlan, C. N., Dissecting the molecular mechanism of IVIg therapy: the interaction between serum IgG and DC-SIGN is independent of antibody glycoform or Fc domain. J Mol Biol 2013, 425 (8), 1253-8.

74. Kanda, Y.; Yamada, T.; Mori, K.; Okazaki, A.; Inoue, M.; Kitajima-Miyama, K.; Kuni-Kamochi, R.; Nakano, R.; Yano, K.; Kakita, S.; Shitara, K.; Satoh, M., Comparison of biological activity among nonfucosylated therapeutic IgG1 antibodies with three different $\mathrm{N}$-linked $\mathrm{Fc}$ oligosaccharides: the high-mannose, hybrid, and complex types. Glycobiology 2007, 17 (1), 104-18.

75. Goetze, A. M.; Liu, Y. D.; Zhang, Z.; Shah, B.; Lee, E.; Bondarenko, P. V.; Flynn, G. C., Highmannose glycans on the $\mathrm{Fc}$ region of therapeutic $\lg \mathrm{G}$ antibodies increase serum clearance in humans. Glycobiology 2011, 21 (7), 949-59.

76. Millward, T. A.; Heitzmann, M.; Bill, K.; Langle, U.; Schumacher, P.; Forrer, K., Effect of constant and variable domain glycosylation on pharmacokinetics of therapeutic antibodies in mice. Biologicals : journal of the International Association of Biological Standardization 2008, 36 (1), 41-7.

77. Li, H.; Sethuraman, N.; Stadheim, T. A.; Zha, D.; Prinz, B.; Ballew, N.; Bobrowicz, P.; Choi, B. K.; Cook, W. J.; Cukan, M.; Houston-Cummings, N. R.; Davidson, R.; Gong, B.; Hamilton, S. R.; Hoopes, J. P.; Jiang, Y.; Kim, N.; Mansfield, R.; Nett, J. H.; Rios, S.; Strawbridge, R.; Wildt, S.; Gerngross, T. U., Optimization of humanized IgGs in glycoengineered Pichia pastoris. Nat Biotechnol 2006, 24 (2), 2105.

78. Calow, J.; Behrens, A. J.; Mader, S.; Bockau, U.; Struwe, W. B.; Harvey, D. J.; Cormann, K. U.; Nowaczyk, M. M.; Loser, K.; Schinor, D.; Hartmann, M. W. W.; Crispin, M., Antibody production using 
a ciliate generates unusual antibody glycoforms displaying enhanced cell-killing activity. Mabs 2016, $8(8), 1498-1511$.

79. Cox, K. M.; Sterling, J. D.; Regan, J. T.; Gasdaska, J. R.; Frantz, K. K.; Peele, C. G.; Black, A.; Passmore, D.; Moldovan-Loomis, C.; Srinivasan, M.; Cuison, S.; Cardarelli, P. M.; Dickey, L. F., Glycan optimization of a human monoclonal antibody in the aquatic plant Lemna minor. Nat Biotechnol 2006, 24 (12), 1591-7.

80. Elbein, A. D.; Tropea, J. E.; Mitchell, M.; Kaushal, G. P., Kifunensine, a potent inhibitor of the glycoprotein processing mannosidase I. J Biol Chem 1990, 265 (26), 15599-605.

81. Bowden, T. A.; Baruah, K.; Coles, C. H.; Harvey, D. J.; Yu, X.; Song, B. D.; Stuart, D. I.; Aricescu, A. R.; Scanlan, C. N.; Jones, E. Y.; Crispin, M., Chemical and structural analysis of an antibody folding intermediate trapped during glycan biosynthesis. J Am Chem Soc 2012, 134 (42), 17554-63.

82. Okeley, N. M.; Alley, S. C.; Anderson, M. E.; Boursalian, T. E.; Burke, P. J.; Emmerton, K. M.; Jeffrey, S. C.; Klussman, K.; Law, C. L.; Sussman, D.; Toki, B. E.; Westendorf, L.; Zeng, W.; Zhang, X.; Benjamin, D. R.; Senter, P. D., Development of orally active inhibitors of protein and cellular fucosylation. Proc Natl Acad Sci U S A 2013, 110 (14), 5404-9.

83. Huang, W.; Giddens, J.; Fan, S. Q.; Toonstra, C.; Wang, L. X., Chemoenzymatic glycoengineering of intact IgG antibodies for gain of functions. Journal of the American Chemical Society 2012, 134 (29), 12308-18.

84. Ahmed, A. A.; Giddens, J.; Pincetic, A.; Lomino, J. V.; Ravetch, J. V.; Wang, L. X.; Bjorkman, P. J., Structural characterization of anti-inflammatory immunoglobulin G Fc proteins. J Mol Biol 2014, 426 (18), 3166-79.

85. Parsons, T. B.; Struwe, W. B.; Gault, J.; Yamamoto, K.; Taylor, T. A.; Raj, R.; Wals, K.; Mohammed, S.; Robinson, C. V.; Benesch, J. L.; Davis, B. G., Optimal Synthetic Glycosylation of a Therapeutic Antibody. Angew Chem Int Ed Engl 2016, 55 (7), 2361-7.

86. Duvic, M.; Evans, M.; Wang, C., Mogamulizumab for the treatment of cutaneous T-cell lymphoma: recent advances and clinical potential. Ther Adv Hematol 2016, 7 (3), 171-4.

87. Goede, V.; Fischer, K.; Busch, R.; Engelke, A.; Eichhorst, B.; Wendtner, C. M.; Chagorova, T.; de la Serna, J.; Dilhuydy, M. S.; Illmer, T.; Opat, S.; Owen, C. J.; Samoylova, O.; Kreuzer, K. A.; Stilgenbauer, S.; Dohner, H.; Langerak, A. W.; Ritgen, M.; Kneba, M.; Asikanius, E.; Humphrey, K.; Wenger, M.; Hallek, M., Obinutuzumab plus chlorambucil in patients with CLL and coexisting conditions. N Engl J Med 2014, 370 (12), 1101-10.

88. Yver, A.; Homery, M. C.; Fuseau, E.; Guemas, E.; Dhainaut, F.; Quagliaroli, D.; Beliard, R.; Prost, J. F., Pharmacokinetics and safety of roledumab, a novel human recombinant monoclonal anti-RhD antibody with an optimized Fc for improved engagement of FCgammaRIII, in healthy volunteers. Vox Sang 2012, 103 (3), 213-22.

89. Subramaniam, J. M.; Whiteside, G.; McKeage, K.; Croxtall, J. C., Mogamulizumab: first global approval. Drugs 2012, 72 (9), 1293-8.

90. Yoshie, O.; Matsushima, K., CCR4 and its ligands: from bench to bedside. Int Immunol 2015, $27(1), 11-20$.

91. Ishii, T.; Ishida, T.; Utsunomiya, A.; Inagaki, A.; Yano, H.; Komatsu, H.; lida, S.; Imada, K.; Uchiyama, T.; Akinaga, S.; Shitara, K.; Ueda, R., Defucosylated humanized anti-CCR4 monoclonal antibody KW-0761 as a novel immunotherapeutic agent for adult T-cell leukemia/lymphoma. Clin Cancer Res 2010, 16 (5), 1520-31.

92. Duvic, M.; Pinter-Brown, L. C.; Foss, F. M.; Sokol, L.; Jorgensen, J. L.; Challagundla, P.; Dwyer, K. M.; Zhang, X.; Kurman, M. R.; Ballerini, R.; Liu, L.; Kim, Y. H., Phase 1/2 study of mogamulizumab, a defucosylated anti-CCR4 antibody, in previously treated patients with cutaneous T-cell lymphoma. Blood 2015, 125 (12), 1883-9.

93. Oldham, R. K.; Dillman, R. O., Monoclonal antibodies in cancer therapy: 25 years of progress. $J$ Clin Oncol 2008, 26 (11), 1774-7.

94. Oldham., R. J.; Cleary., K. L. S.; Cragg., M. S., CD20 and Its Antibodies: Past, Present, and Future. Forum on Immunopathological Diseases and Therapeutics 2014, 5 (1-2), 7-23. 
95. Sehn, L. H.; Chua, N.; Mayer, J.; Dueck, G.; Trneny, M.; Bouabdallah, K.; Fowler, N.; Delwail, V.; Press, O.; Salles, G.; Gribben, J.; Lennard, A.; Lugtenburg, P. J.; Dimier, N.; Wassner-Fritsch, E.; FingerleRowson, G.; Cheson, B. D., Obinutuzumab plus bendamustine versus bendamustine monotherapy in patients with rituximab-refractory indolent non-Hodgkin lymphoma (GADOLIN): a randomised, controlled, open-label, multicentre, phase 3 trial. Lancet Oncol 2016, 17 (8), 1081-93.

96. Cameron, F.; McCormack, P. L., Obinutuzumab: first global approval. Drugs 2014, 74 (1), 147-

54.

97. Mossner, E.; Brunker, P.; Moser, S.; Puntener, U.; Schmidt, C.; Herter, S.; Grau, R.; Gerdes, C.; Nopora, A.; van Puijenbroek, E.; Ferrara, C.; Sondermann, P.; Jager, C.; Strein, P.; Fertig, G.; Friess, T.; Schull, C.; Bauer, S.; Dal Porto, J.; Del Nagro, C.; Dabbagh, K.; Dyer, M. J.; Poppema, S.; Klein, C.; Umana, $P .$, Increasing the efficacy of CD20 antibody therapy through the engineering of a new type II antiCD20 antibody with enhanced direct and immune effector cell-mediated B-cell cytotoxicity. Blood 2010, 115 (22), 4393-402.

98. Herter, S.; Birk, M. C.; Klein, C.; Gerdes, C.; Umana, P.; Bacac, M., Glycoengineering of therapeutic antibodies enhances monocyte/macrophage-mediated phagocytosis and cytotoxicity. $J$ Immunol 2014, 192 (5), 2252-60.

99. Herter, S.; Herting, F.; Mundigl, O.; Waldhauer, I.; Weinzierl, T.; Fauti, T.; Muth, G.; ZieglerLandesberger, D.; Van Puijenbroek, E.; Lang, S.; Duong, M. N.; Reslan, L.; Gerdes, C. A.; Friess, T.; Baer, U.; Burtscher, H.; Weidner, M.; Dumontet, C.; Umana, P.; Niederfellner, G.; Bacac, M.; Klein, C., Preclinical activity of the type II CD20 antibody GA101 (obinutuzumab) compared with rituximab and ofatumumab in vitro and in xenograft models. Mol Cancer Ther 2013, 12 (10), 2031-42.

100. Bournazos, S.; Woof, J. M.; Hart, S. P.; Dransfield, I., Functional and clinical consequences of Fc receptor polymorphic and copy number variants. Clin Exp Immunol 2009, 157 (2), 244-54.

101. Goede, V.; Fischer, K.; Humphrey, K.; Asikanius, E.; Busch, R.; Engelke, A.; Wendtner, C. M.; Samoylova, O.; Chagorova, T.; Dilhuydy, M. S.; Torroba, J. D.; Illmer, T.; Opat, S.; Owen, C.; Kreuzer, K. A.; Langerak, A. W.; Ritgen, M.; Stilgenbauer, S.; Wenger, M.; Hallek, M., Obinutuzumab (GA101) plus chlorambucil $(\mathrm{Clb})$ or rituximab $(\mathrm{R})$ plus $\mathrm{Clb}$ versus $\mathrm{Clb}$ alone in patients with chronic lymphocytic leukemia (CLL) and preexisting medical conditions (comorbidities): Final stage 1 results of the CLL11 (BO21004) phase III trial. Journal of Clinical Oncology 2013, 31 (15).

102. Goede, V.; Fischer, K.; Busch, R.; Engelke, A.; Eichhorst, B.; Wendtner, C. M.; Chagorova, T.; De la Serna, J.; Dilhuydy, M. S.; Opat, S.; Owen, C. J.; Samoylova, O.; Kreuzer, K. A.; Langerak, A. W.; Ritgen, M.; Stilgenbauer, S.; Dohner, H.; Asikanius, E.; Humphrey, K.; Wenger, M. K.; Hallek, M., Head-To-Head Comparison Of Obinutuzumab (GA101) Plus Chlorambucil (Clb) Versus Rituximab Plus Clb In Patients With Chronic Lymphocytic Leukemia (CLL) and Co-Existing Medical Conditions (Comorbidities): Final Stage 2 Results Of The CLL11 Trial. Blood 2013, 122 (21).

103. Klein, C.; Lammens, A.; Schafer, W.; Georges, G.; Schwaiger, M.; Mossner, E.; Hopfner, K. P.; Umana, P.; Niederfellner, G., Epitope interactions of monoclonal antibodies targeting CD20 and their relationship to functional properties. MAbs 2013, 5 (1), 22-33.

104. Deans, J. P.; Robbins, S. M.; Polyak, M. J.; Savage, J. A., Rapid redistribution of CD20 to a low density detergent-insoluble membrane compartment. J Biol Chem 1998, 273 (1), 344-8.

105. Cragg, M. S.; Morgan, S. M.; Chan, H. T.; Morgan, B. P.; Filatov, A. V.; Johnson, P. W.; French, R. R.; Glennie, M. J., Complement-mediated lysis by anti-CD20 mAb correlates with segregation into lipid rafts. Blood 2003, 101 (3), 1045-52.

106. Tipton, T. R.; Roghanian, A.; Oldham, R. J.; Carter, M. J.; Cox, K. L.; Mockridge, C. I.; French, R. R.; Dahal, L. N.; Duriez, P. J.; Hargreaves, P. G.; Cragg, M. S.; Beers, S. A., Antigenic modulation limits the effector cell mechanisms employed by type I anti-CD20 monoclonal antibodies. Blood 2015, 125 (12), 1901-9.

107. Arteaga, C. L.; Sliwkowski, M. X.; Osborne, C. K.; Perez, E. A.; Puglisi, F.; Gianni, L., Treatment of HER2-positive breast cancer: current status and future perspectives. Nat Rev Clin Oncol 2011, 9 (1), 16-32. 
108. Junttila, T. T.; Akita, R. W.; Parsons, K.; Fields, C.; Phillips, G. D. L.; Friedman, L. S.; Sampath, D.; Sliwkowski, M. X., Ligand-Independent HER2/HER3/PI3K Complex Is Disrupted by Trastuzumab and Is Effectively Inhibited by the PI3K Inhibitor GDC-0941. Cancer cell 2009, 15 (5), 429-440.

109. Yakes, F. M.; Chinratanalab, W.; Ritter, C. A.; King, W.; Seelig, S.; Arteaga, C. L., Herceptininduced inhibition of phosphatidylinositol-3 kinase and Akt Is required for antibody-mediated effects on p27, cyclin D1, and antitumor action. Cancer Res 2002, 62 (14), 4132-41.

110. Listinsky, J. J.; Siegal, G. P.; Listinsky, C. M., Glycoengineering in cancer therapeutics: a review with fucose-depleted trastuzumab as the model. Anticancer Drugs 2013, 24 (3), 219-27.

111. Musolino, A.; Naldi, N.; Bortesi, B.; Pezzuolo, D.; Capelletti, M.; Missale, G.; Laccabue, D.; Zerbini, A.; Camisa, R.; Bisagni, G.; Neri, T. M.; Ardizzoni, A., Immunoglobulin G fragment C receptor polymorphisms and clinical efficacy of trastuzumab-based therapy in patients with HER-2/neu-positive metastatic breast cancer. J Clin Oncol 2008, 26 (11), 1789-96.

112. Junttila, T. T.; Parsons, K.; Olsson, C.; Lu, Y.; Xin, Y.; Theriault, J.; Crocker, L.; Pabonan, O.; Baginski, T.; Meng, G.; Totpal, K.; Kelley, R. F.; Sliwkowski, M. X., Superior in vivo efficacy of afucosylated trastuzumab in the treatment of HER2-amplified breast cancer. Cancer Res 2010, 70 (11), 4481-9.

113. Amado, R. G.; Wolf, M.; Peeters, M.; Van Cutsem, E.; Siena, S.; Freeman, D. J.; Juan, T.; Sikorski, R.; Suggs, S.; Radinsky, R.; Patterson, S. D.; Chang, D. D., Wild-type KRAS is required for panitumumab efficacy in patients with metastatic colorectal cancer. Journal of Clinical Oncology 2008, 26 (10), 16261634.

114. Lievre, A.; Bachet, J. B.; Le Corre, D.; Boige, V.; Landi, B.; Emile, J. F.; Cote, J. F.; Tomasic, G.; Penna, C.; Ducreux, M.; Rougier, P.; Penault-Llorca, F.; Laurent-Puig, P., KRAS mutation status is predictive of response to cetuximab therapy in colorectal cancer. Cancer Research 2006, 66 (8), 39923995.

115. Goldstein, N. I.; Prewett, M.; Zuklys, K.; Rockwell, P.; Mendelsohn, J., Biological efficacy of a chimeric antibody to the epidermal growth factor receptor in a human tumor xenograft model. Clin Cancer Res 1995, 1 (11), 1311-8.

116. Gerdes, C. A.; Nicolini, V. G.; Herter, S.; van Puijenbroek, E.; Lang, S.; Roemmele, M.; Moessner, E.; Freytag, O.; Friess, T.; Ries, C. H.; Bossenmaier, B.; Mueller, H. J.; Umana, P., GA201 (RG7160): a novel, humanized, glycoengineered anti-EGFR antibody with enhanced ADCC and superior in vivo efficacy compared with cetuximab. Clin Cancer Res 2013, 19 (5), 1126-38.

117. Paz-Ares, L. G.; Gomez-Roca, C.; Delord, J. P.; Cervantes, A.; Markman, B.; Corral, J.; Soria, J. C.; Berge, Y.; Roda, D.; Russell-Yarde, F.; Hollingsworth, S.; Baselga, J.; Umana, P.; Manenti, L.; Tabernero, J., Phase I pharmacokinetic and pharmacodynamic dose-escalation study of RG7160 (GA201), the first glycoengineered monoclonal antibody against the epidermal growth factor receptor, in patients with advanced solid tumors. J Clin Oncol 2011, 29 (28), 3783-90.

118. Poliakov, A.; Cotrina, M.; Wilkinson, D. G., Diverse roles of eph receptors and ephrins in the regulation of cell migration and tissue assembly. Dev Cell 2004, 7 (4), 465-80.

119. Swords, R. T.; Greenberg, P. L.; Wei, A. H.; Durrant, S.; Advani, A. S.; Hertzberg, M. S.; Lewis, I. D.; Rivera, G.; Gratzinger, D.; Fan, A. C.; Felsher, D. W.; Cortes, J. E.; Watts, J. M.; Yarranton, G. T.; Walling, J. M.; Lancet, J. E., KB004, a first in class monoclonal antibody targeting the receptor tyrosine kinase EphA3, in patients with advanced hematologic malignancies: Results from a phase 1 study. Leuk Res 2016, 50, 123-131.

120. Swords, R. T.; Wei, A. H.; Durrant, S.; Advani, A. S.; Hertzberg, M. S.; Lewis, I. D.; Greenberg, P. L.; Cortes, J. E.; Yarranton, G. T.; Walling, J. M.; Lancet, J. E., KB004, a Novel Non-Fucosylated Humaneered (R) Antibody, Targeting EphA3, Is Active and Well Tolerated in a Phase I/II Study of Advanced Hematologic Malignancies. Blood 2014, 124 (21).

121. Naddafi, F.; Davami, F., Anti-CD19 Monoclonal Antibodies: a New Approach to Lymphoma Therapy. Int J Mol Cell Med 2015, 4 (3), 143-51.

122. Vlasveld, L. T.; Hekman, A.; Vythdreese, F. A.; Melief, C. J. M.; Sein, J. J.; Voordouw, A. C.; Dellemijn, T. A. M.; Rankin, E. M., Treatment of Low-Grade Non-Hodgkins-Lymphoma with 
Continuous-Infusion of Low-Dose Recombinant Interleukin-2 in Combination with the B-Cell-Specific Monoclonal-Antibody Clb-Cd19. Cancer Immunol Immun 1995, 40 (1), 37-47.

123. Hekman, A.; Honselaar, A.; Vuist, W. M.; Sein, J. J.; Rodenhuis, S.; ten Bokkel Huinink, W. W.; Somers, R.; Rumke, P.; Melief, C. J., Initial experience with treatment of human B cell lymphoma with anti-CD19 monoclonal antibody. Cancer Immunol Immunother 1991, 32 (6), 364-72.

124. Cardarelli, P. M.; Rao-Naik, C.; Chen, S.; Huang, H.; Pham, A.; Moldovan-Loomis, M. C.; Pan, C.; Preston, B.; Passmore, D.; Liu, J.; Kuhne, M. R.; Witte, A.; Blanset, D.; King, D. J., A nonfucosylated human antibody to CD19 with potent B-cell depletive activity for therapy of B-cell malignancies. Cancer Immunol Immunother 2010, 59 (2), 257-65.

125. Herbst, R.; Wang, Y.; Gallagher, S.; Mittereder, N.; Kuta, E.; Damschroder, M.; Woods, R.; Rowe, D. C.; Cheng, L.; Cook, K.; Evans, K.; Sims, G. P.; Pfarr, D. S.; Bowen, M. A.; Dall'Acqua, W.; Shlomchik, M.; Tedder, T. F.; Kiener, P.; Jallal, B.; Wu, H.; Coyle, A. J., B-cell depletion in vitro and in vivo with an afucosylated anti-CD19 antibody. The Journal of pharmacology and experimental therapeutics 2010, $335(1), 213-22$

126. Camacho, L. H.; Joyce, R.; Brown, J. R.; Chanan-Khan, A.; Amrein, P. C.; Assad, A.; Carrigan, M., A Phase 1, Open-Label, Multi-Center, Multiple-Dose, Dose-Escalation Study of MDX-1342 in Patients with CD19-Positive Refractory/Relapsed Chronic Lymphocytic Leukemia. Blood 2009, 114 (22), 13301330.

127. Hammer, O., CD19 as an attractive target for antibody-based therapy. Mabs 2012, 4 (5), 571 -

577.

128. Ward, E.; Mittereder, N.; Kuta, E.; Sims, G. P.; Bowen, M. A.; Dall'Acqua, W.; Tedder, T.; Kiener, P.; Coyle, A. J.; Wu, H.; Jallal, B.; Herbst, R., A glycoengineered anti-CD19 antibody with potent antibody-dependent cellular cytotoxicity activity in vitro and lymphoma growth inhibition in vivo. $\mathrm{Br} J$ Haematol 2011, 155 (4), 426-37.

129. Hamadani, M.; Forero, A.; Kipps, T. J.; Fanale, M. A.; Cuneo, A.; de Oteyza, J. P.; Gladstone, D.; Goswami, T.; Ibrahim, R. A.; Liang, M. N.; Eck, S.; Elgeioushi, N.; Herbst, R.; Cheson, B. D., MEDI-551, an anti-CD19 antibody active in chronic lymphocytic leukemia (CLL) patients previously treated with rituximab. Journal of Clinical Oncology 2013, 31 (15).

130. Goswami, T.; Forero, A.; Hamadani, M.; Sonet, A.; Verhoef, G.; Fanale, M. A.; Bello, C. M.; Huang, W. M.; Cheson, B. D., Phase I/II study of MEDI-551, a humanized monoclonal antibody targeting CD19, in subjects with relapsed or refractory advanced B-cell malignancies. Journal of Clinical Oncology 2012, 30 (15).

131. Senter, P. D.; Sievers, E. L., The discovery and development of brentuximab vedotin for use in relapsed Hodgkin lymphoma and systemic anaplastic large cell lymphoma. Nat Biotechnol 2012, 30 (7), 631-7.

132. Younes, A.; Bartlett, N. L.; Leonard, J. P.; Kennedy, D. A.; Lynch, C. M.; Sievers, E. L.; ForeroTorres, A., Brentuximab vedotin (SGN-35) for relapsed CD30-positive lymphomas. N Engl J Med 2010, 363 (19), 1812-21.

133. Ansell, S. M.; Horwitz, S. M.; Engert, A.; Khan, K. D.; Lin, T.; Strair, R.; Keler, T.; Graziano, R.; Blanset, D.; Yellin, M.; Fischkoff, S.; Assad, A.; Borchmann, P., Phase I/II study of an anti-CD30 monoclonal antibody (MDX-060) in Hodgkin's lymphoma and anaplastic large-cell lymphoma. $J$ Clin Oncol 2007, 25 (19), 2764-9.

134. Cardarelli, P. M.; Moldovan-Loomis, M. C.; Preston, B.; Black, A.; Passmore, D.; Chen, T. H.; Chen, S.; Liu, J.; Kuhne, M. R.; Srinivasan, M.; Assad, A.; Witte, A.; Graziano, R. F.; King, D. J., In vitro and in vivo characterization of MDX-1401 for therapy of malignant lymphoma. Clin Cancer Res 2009, 15 (10), 3376-83.

135. Thertulien, R.; Frankel, A.; Evens, A.; Kaufman, J.; Horwitz, S.; Assad, A.; Cardarelli, P.; Tian, J.; Zhang, Z. S.; MacDowall, M., A phase I, open-label, dose-escalation, multidose study of MDX-1401 (defucosylated human antiCD30 monoclonal antibody) in patients with CD30-positive refractory/relapsed HodgkiM\#8217; s lymphoma. Cancer Research 2009, 69. 
136. Watanabe, M.; Yamashita, K.; Suzuki, T.; Kamachi, H.; Kuraya, D.; Koshizuka, Y.; Ogura, M.; Yoshida, T.; Aoyagi, T.; Fukumori, D.; Shimamura, T.; Okimura, K.; Maeta, K.; Miura, T.; Sakai, F.; Todo, S., ASKP1240, a fully human anti-CD40 monoclonal antibody, prolongs pancreatic islet allograft survival in nonhuman primates. Am J Transplant 2013, 13 (8), 1976-88.

137. Elgueta, R.; Benson, M. J.; de Vries, V. C.; Wasiuk, A.; Guo, Y.; Noelle, R. J., Molecular mechanism and function of CD40/CD40L engagement in the immune system. Immunol Rev 2009, 229 (1), 152-72.

138. Gardai, S. J.; Epp, A.; Linares, G.; Westendorf, L.; Sutherland, M. K.; Neff-LaFord, H.; Drachman, J. G.; Peng, S.; Law, C. L., A sugar engineered non-fucosylated anti-CD40 antibody, SEA-CD40, with enhanced immune stimulatory activity alone and in combination with immune checkpoint inhibitors. Journal of Clinical Oncology 2015, 33 (15).

139. Gardai, S. J.; Epp, A.; Linares, G.; Westendorf, L.; Sutherland, M.; Neff-LaFord, H.; Peng, S. L.; Law, C. L., SEA-CD40, a sugar engineered non-fucosylated anti-CD40 antibody with improved immune activating capabilities. Cancer Research 2015, 75.

140. de Vos, S.; Forero-Torres, A.; Ansell, S. M.; Kahl, B.; Cheson, B. D.; Bartlett, N. L.; Furman, R. R.; Winter, J. N.; Kaplan, H.; Timmerman, J.; Whiting, N. C.; Drachman, J. G.; Advani, R., A phase II study of dacetuzumab (SGN-40) in patients with relapsed diffuse large B-cell lymphoma (DLBCL) and correlative analyses of patient-specific factors. J Hematol Oncol 2014, 7, 44.

141. Furman, R. R.; Forero-Torres, A.; Shustov, A.; Drachman, J. G., A phase I study of dacetuzumab (SGN-40, a humanized anti-CD40 monoclonal antibody) in patients with chronic lymphocytic leukemia. Leukemia Lymphoma 2010, 51 (2), 228-235.

142. Law, C. L.; Gordon, K. A.; Collier, J.; Klussman, K.; McEarchern, J. A.; Cerveny, C. G.; Mixan, B. J.; Lee, W. P.; Lin, Z.; Valdez, P.; Wahl, A. F.; Grewal, I. S., Preclinical antilymphoma activity of a humanized anti-CD40 monoclonal antibody, SGN-40. Cancer Res 2005, 65 (18), 8331-8.

143. Laabi, Y.; Gras, M. P.; Brouet, J. C.; Berger, R.; Larsen, C. J.; Tsapis, A., The Bcma Gene, Preferentially Expressed during B-Lymphoid Maturation, Is Bidirectionally Transcribed. Nucleic Acids Res 1994, 22 (7), 1147-1154.

144. Laabi, Y.; Gras, M. P.; Carbonnel, F.; Brouet, J. C.; Berger, R.; Larsen, C. J.; Tsapis, A., A New Gene, Bcm, on Chromosome-16 Is Fused to the Interleukin-2 Gene by a T(4-16)(Q26-P13) Translocation in a Malignant T-Cell Lymphoma. Embo J 1992, 11 (11), 3897-3904.

145. MacLennan, I.; Vinuesa, C., Dendritic cells, BAFF, and APRIL: innate players in adaptive antibody responses. Immunity 2002, 17 (3), 235-8.

146. O'Connor, B. P.; Raman, V. S.; Erickson, L. D.; Cook, W. J.; Weaver, L. K.; Ahonen, C.; Lin, L. L.; Mantchev, G. T.; Bram, R. J.; Noelle, R. J., BCMA is essential for the survival of long-lived bone marrow plasma cells. Journal of Experimental Medicine 2004, 199 (1), 91-97.

147. Carpenter, R. O.; Evbuomwan, M. O.; Pittaluga, S.; Rose, J. J.; Raffeld, M.; Yang, S. C.; Gress, R. E.; Hakim, F. T.; Kochenderfer, J. N., B-cell Maturation Antigen Is a Promising Target for Adoptive Tcell Therapy of Multiple Myeloma. Clinical Cancer Research 2013, 19 (8), 2048-2060.

148. Tai, Y. T.; Mayes, P. A.; Acharya, C.; Zhong, M. Y.; Cea, M.; Cagnetta, A.; Craigen, J.; Yates, J.; Gliddon, L.; Fieles, W.; Hoang, B.; Tunstead, J.; Christie, A. L.; Kung, A. L.; Richardson, P.; Munshi, N. C.; Anderson, K. C., Novel anti-B-cell maturation antigen antibody-drug conjugate (GSK2857916) selectively induces killing of multiple myeloma. Blood 2014, 123 (20), 3128-3138.

149. van Geel, R.; Wijdeven, M. A.; Heesbeen, R.; Verkade, J. M. M.; Wasiel, A. A.; van Berkel, S. S.; van Delft, F. L., Chemoenzymatic Conjugation of Toxic Payloads to the Globally Conserved N-Glycan of Native mAbs Provides Homogeneous and Highly Efficacious Antibody-Drug Conjugates. Bioconjugate Chem 2015, 26 (11), 2233-2242.

150. Qasba, P. K., Glycans of Antibodies as a Specific Site for Drug Conjugation Using Glycosyltransferases. Bioconjugate Chem 2015, 26 (11), 2170-2175.

151. Li, X.; Fang, T.; Boons, G. J., Preparation of well-defined antibody-drug conjugates through glycan remodeling and strain-promoted azide-alkyne cycloadditions. Angew Chem Int Ed Engl 2014, 53 (28), 7179-82. 
152. Zhou, Q.; Stefano, J. E.; Manning, C.; Kyazike, J.; Chen, B.; Gianolio, D. A.; Park, A.; Busch, M.; Bird, J.; Zheng, X. Y.; Simonds-Mannes, H.; Kim, J.; Gregory, R. C.; Miller, R. J.; Brondyk, W. H.; Dhal, P. K.; Pan, C. Q., Site-Specific Antibody-Drug Conjugation through Glycoengineering. Bioconjugate Chem 2014, 25 (3), 510-520.

153. Zuberbuhler, K.; Casi, G.; Bernardes, G. J.; Neri, D., Fucose-specific conjugation of hydrazide derivatives to a vascular-targeting monoclonal antibody in IgG format. Chem Commun (Camb) 2012, 48 (56), 7100-2.

154. Beck, A.; Goetsch, L.; Dumontet, C.; Corvaia, N., Strategies and challenges for the next generation of antibody-drug conjugates. Nat Rev Drug Discov 2017.

155. Largy, E.; Cantais, F.; Van Vyncht, G.; Beck, A.; Delobel, A., Orthogonal LC/MS methods for the comprehensive characterization of therapeutic glycoproteins, from released glycans to intact protein level. J Chromatogr A 2017.

156. Ishida, T.; Joh, T.; Uike, N.; Yamamoto, K.; Utsunomiya, A.; Yoshida, S.; Saburi, Y.; Miyamoto, T.; Takemoto, S.; Suzushima, H.; Tsukasaki, K.; Nosaka, K.; Fujiwara, H.; Ishitsuka, K.; Inagaki, H.; Ogura, M.; Akinaga, S.; Tomonaga, M.; Tobinai, K.; Ueda, R., Defucosylated anti-CCR4 monoclonal antibody (KW-0761) for relapsed adult T-cell leukemia-lymphoma: a multicenter phase II study. J Clin Oncol 2012, 30 (8), 837-42.

157. Duvic, M.; Pinter-Brown, L.; Foss, F. M.; Sokol, L.; Jorgensen, J.; Spitalny, G. L.; Kim, Y. H., Results of a Phase 1/2 Study for KW-0761, a Monoclonal Antibody Directed Against CC Chemokine Receptor Type 4 (CCR4), In CTCL Patients. Blood 2010, 116 (21), 424-424.

158. Gladstone, D.; Andre, M.; Jan, Z. C.; Assouline, S.; Bellam, N.; Cascavilla, N.; Jourdan, E.; Panwalkar, A.; Patti, C.; Schulte, C.; Zaja, F.; Goswami, T.; Elgeioushi, N.; Streicher, K.; Bao, H. F.; Spaner D., Results of a Phase 2 Study of MEDI-551 and Bendamustine Vs Rituximab and Bendamustine in Relapsed or Refractory Chronic Lymphocytic Leukemia. Blood 2014, 124 (21).

159. Forero-Torres, A.; Hamadani, M.; Fanale, M. A.; Bello, C. M.; Kipps, T. J.; Offner, F.; Verhoef, G.; Federico, M.; Gregory, S. A.; Sonet, A.; Assouline, S.; de Oteyza, J. P.; Tomas, J. F.; Cuneo, A.; Elgeioushi, N.; Goswami, T.; Ibrahim, R.; Herbst, R.; Cheson, B. D., Safety Profile and Clinical Response To MEDI-551, a Humanized Monoclonal Anti-CD19, In a Phase 1/2 Study In Adults With Relapsed Or Refractory Advanced B-Cell Malignancies. Blood 2013, 122 (21).

\section{FIGURE LEGEND}

Figure 1. Structural basis of afucosylation-mediated enhancement of $\mathrm{IgG}$ receptor interaction. Crystal structures of fucosylated and afucosylated IgG1 Fc in complex with Fc $\gamma$ RIIIa containing a glycan at Asn 162 reported by Ferrara et al. ${ }^{48}$. The Fc $\gamma$ RIIIa component is shown in orange with transparent surface representation and cartoon representation of the protein chain. The Fc $\gamma$ RIIIa glycan at Asn162 is shown in either red or green respectively for the structure containing $\mathrm{Fc}$ fucose and that without $\mathrm{Fc}$ fucose. The Fc protein is shown in grey with transparent surface and cartoon representation of the protein chain. Fc glycans are shown as sticks. The steric clash between the receptor glycan and the Fc fucose is highlighted by cartoon clash symbols. 
Table 1- List of fucose-engineered mAbs for cancer treatment

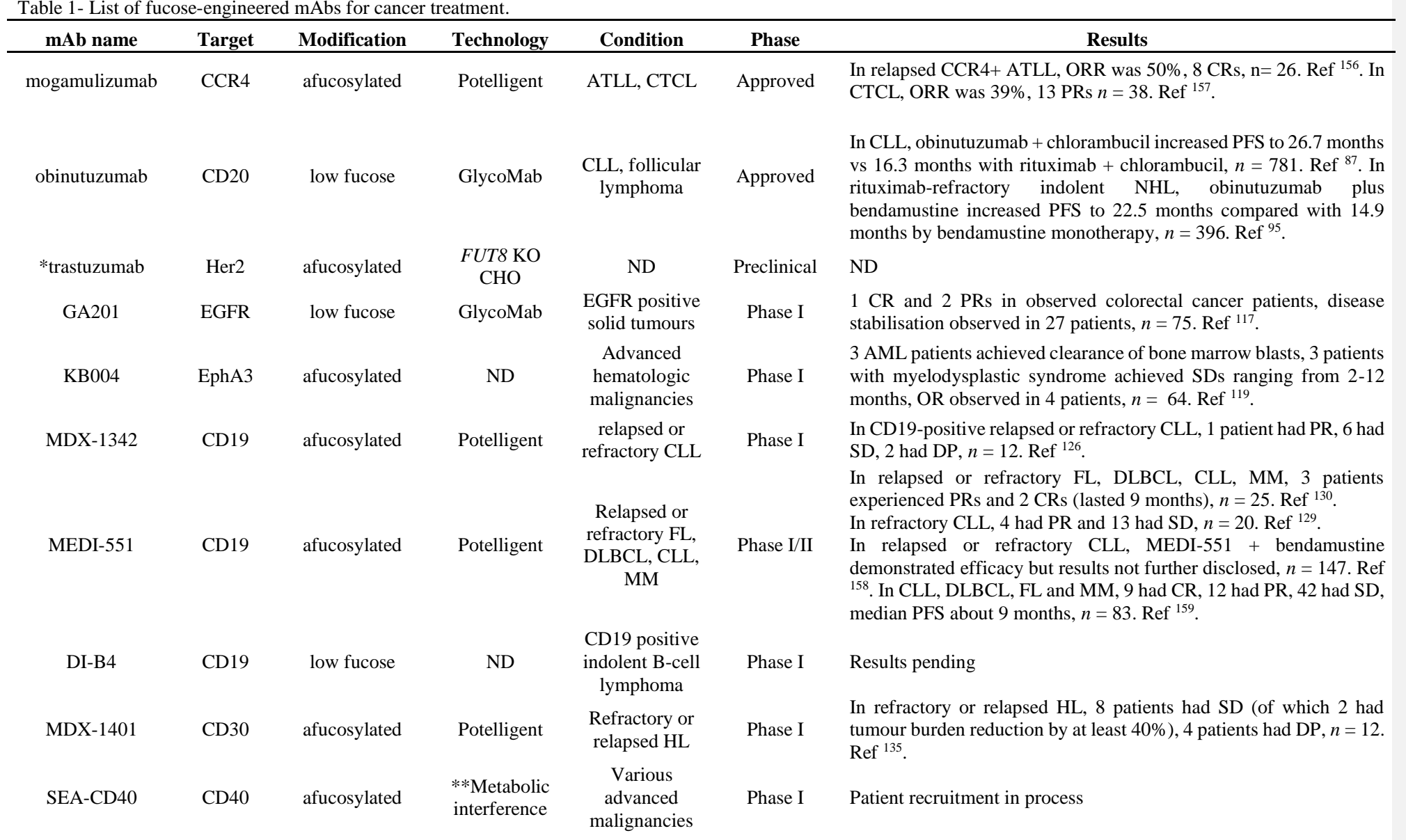


J6M0-mcMMAF BCMA

*afucosylated trastuzumab

**this production method is inferred from related patents filed by Seattle Genetics, Inc., the company which developed SEA-40

Abbreviations: ORR- overall response rate; PFS- progression-free survival; CR- complete response; PR- partial response; OR- objective response; SD- stable disease; DP-

disease progression; AML- acute myeloid leukaemia; MM- multiple myeloma; ND- not disclosed 
